\title{
Cancer stem cells in basic science and in translational oncology: can we translate into clinical application?
}

\author{
Axel Schulenburg ${ }^{1,2,7^{*}}$, Katharina Blatt ${ }^{3}$, Sabine Cerny-Reiterer ${ }^{2,3}$, Irina Sadovnik ${ }^{3}$, Harald Herrmann ${ }^{2,4}$, \\ Brigitte Marian ${ }^{2,5}$, Thomas W Grunt ${ }^{2,6}$, Christoph C Zielinski ${ }^{2,6}$ and Peter Valent ${ }^{2,3}$
}

\begin{abstract}
Since their description and identification in leukemias and solid tumors, cancer stem cells (CSC) have been the subject of intensive research in translational oncology. Indeed, recent advances have led to the identification of CSC markers, CSC targets, and the preclinical and clinical evaluation of the CSC-eradicating (curative) potential of various drugs. However, although diverse CSC markers and targets have been identified, several questions remain, such as the origin and evolution of CSC, mechanisms underlying resistance of CSC against various targeted drugs, and the biochemical basis and function of stroma cell-CSC interactions in the so-called 'stem cell niche.' Additional aspects that have to be taken into account when considering CSC elimination as primary treatment-goal are the genomic plasticity and extensive subclone formation of CSC. Notably, various cell fractions with different combinations of molecular aberrations and varying proliferative potential may display CSC function in a given neoplasm, and the related molecular complexity of the genome in CSC subsets is considered to contribute essentially to disease evolution and acquired drug resistance. In the current article, we discuss new developments in the field of CSC research and whether these new concepts can be exploited in clinical practice in the future.
\end{abstract}

Keywords: Cancer stem cells, Targeted therapy, Drug resistance

\section{Introduction}

The principle concept of cancer stem cells (CSC) has gained increasing acceptance in recent years [1-10]. By definition, CSC exhibit self-renewal activity and longterm cancer-propagating capacity [1-9]. By contrast, more mature clonal cells in the same neoplasm have limited proliferative potential. In leukemias, CSC are also known as leukemic stem cells (LSC) [5,8,11-18]. The concept of neoplastic stem cells may provide explanations for the failure of various cytoreductive agents to produce long-lasting responses in patients [1-9,11,15-18]. Notably, in many instances, antineoplastic drugs act on more mature neoplastic cells rather than CSC/LSC, a phenomenon that is explained in

\footnotetext{
* Correspondence: axel.schulenburg@meduniwien.ac.at

'Bone Marrow Transplantation Unit, Department of Internal Medicine I, Medical University of Vienna, Währinger Gürtel 18-20, Vienna A-1090, Wien, Austria

${ }^{2}$ Ludwig Boltzmann Cluster Oncology, Medical University of Vienna, Spitalgasse 23, Vienna 1090, Wien, Austria

Full list of author information is available at the end of the article
}

part by the fact that these cells exhibit intrinsic resistance [19-23]. Moreover, CSC often develop acquired drug resistance and thus produce more malignant subclones over time [11,24-26].

All these observations point to the need to develop new CSC-eliminating treatment strategies through which cure rates and survival can be improved [16,27-31]. In other words, CSC have been recognized as a major 'target cell population' in oncology in recent years, and considerable effort has been made to identify novel CSC markers and target expression profiles and to measure responses of these cells to various targeted drugs.

The present article provides a summary of our knowledge on CSC/LSC, with special focus on the possibility to translate CSC/LSC-targeting treatment concepts into clinical application. Unless otherwise stated, this article refers to CSC/LSC in primary human malignancies. With regard to cell line models and engineered CSC-like 
cells or other more 'artificial' models that may also support CSC research, we refer to the published literature.

\section{Definition and function of cancer stem cells}

In contrast to more mature cancer cells, CSC are selfrenewing cells with long-term proliferative potential $[1-9,11]$. As a result, CSC can maintain a given neoplasm for prolonged time periods. In most cases, these cells can also produce a cancer (CSC) or leukemia (LSC) in immunodeficient mice (xenotransplantation model) which enables their detection and quantification [1-9,32,33]. Previous studies have used non-obese diabetic mice with severe combined immunodeficiency (NOD/SCID) [1-3,5,6,32,33]. In several tumor models, this mouse strain is a sufficient or even a preferable model to study CSC biology [34]. However, more recent data suggest that in several primary malignancies, NOD/ SCID with loss-of-function-mutated IL-2Rgamma chain or IL-2Rgamma chain-knock out NOD/shi-SCID mice (NSG or NOG mice) provide superior engraftment rates [35-38]. Therefore, many current studies on primary CSC/LSC employ NSG mice. Depending on the type of disease, neoplastic cells are injected intravenously, subcutaneously, or directly into solid organs (orthotopic application) [27,39-44]. An important point is that 'short-term engraftment' (or just simple maintenance) of tumor/leukemic cells has to be differentiated from longterm engraftment, only the latter being indicative of the presence of functionally active (self-renewing) CSC. Long-term engraftment and growth of cancers/leukemias is best demonstrable by recovering engrafted cells from primary recipient mice and injecting these cells into secondary recipient animals [32,39,40,42,43,45-47].

Despite advanced technologies and novel mouse models, xenotransplantation assays for human CSC have several limitations. First, the microenvironment is often species-specific or tumor-specific. Second, in a neoplasm with low growth-rate (for example, indolent/low-grade/ chronic tumor; premalignant neoplasms), the development phase of the neoplasm may exceed the lifetime of a mouse. Moreover, the CSC pool is composed of heterogeneous populations of tumor-initiating cells with subclone-specific molecular properties and varying growth characteristics in vivo $[11,25,26,28,48]$. Some of the CSC may be recognized (and eliminated) by the residual immune system of xeno-transplanted mice $[37,38]$. On the other hand, the lack of a natural immune system and thus tumor immune surveillance in highly immunodeficient mice may facilitate the uncontrolled expansion of clinically irrelevant sub-clones. Therefore, several attempts are currently made to establish NSGmouse models harboring a human immune system.

A frequently discussed alternative to in vivo xenotransplantation studies are in vitro long-term culture experiments to study the growth and maintenance of CSC [47,49-53]. Although helpful as a screen approach, these assays are not sufficient for evaluating the in vivo self-renewal capacity of 'true' CSC. Several in vitro assays employ stromal cells which may provide some of the 'niche-factors' required for long-term growth CSC [47,49-53]. Solid tumor cells often grow in 'spheres' or clusters for prolonged time periods in such assays [47,49-53]. However, as mentioned above, the available in vitro assays cannot replace in vivo xenotransplantation models when long-term self renewal and tumor propagation should be examined.

\section{Identification and enrichment of CSC/LSC}

Several different approaches, through which CSC/LSC can be identified and enriched in primary cancer/ leukemia samples, have been developed in the past [1-3,5-7,9,11-13,27,54-61]. A widely applied strategy is to use antibodies directed against certain cell surface antigens that are (or are not) expressed on CSC [1-3,5-7,9,11-13,27]. Expression of surface antigens is best determined by multicolor flow cytometry. Enrichment of CSC/LSC can be performed by fluorescenceactivated cell sorting (FACS) or magnetic cell sorting [1-9,13,15-18,62-69]. Both techniques have certain limitations. One general problem is that the 'so-called' stem cell markers are often not specific for CSC or LSC. Likewise, the stem cell-related antigen CD34 is not only expressed on hematopoietic stem cells but also on myeloid progenitor cells and endothelial cells, and KIT is not only expressed on hematopoietic stem- and progenitor cells but also on mast cells, germ cells, and melanocytes [70,71]. Therefore, it is essential to apply combinations of antibodies when detecting and analyzing CSC/LSC in various tissues. Usually, one or two organ-specific markers are employed to confirm the primary origin of cells (Tables 1 and 2). The panhematopoietic marker CD45 is widely used to confirm the hematopoietic origin of cells or to exclude leukocytes in primary fractions obtained from solid tumors. Additional antibodies are applied to delineate CSC from more mature neoplastic cells [1-3,5-7,9,11-13,27,65 $-69,72,73]$. In case of myeloid leukemias, the antigen profiles of more mature cells are well defined, and the approach to deplete these ( $\operatorname{Lin}+)$ cells from LSC is well established. However, in certain leukemias, LSC may aberrantly express one or even several of the 'lineage-related' antigens. In such leukemias, application of the 'Lin-cocktail' may lead to a loss of LSC subsets. Another problem is that antibody-bound cells may be detected and eliminated by the residual immune system of NOD/ SCID mice. This problem has been outlined in acute myeloid leukemia (AML) where CD38+ cells (CD38 antibody-laden) may be cleared by the residual immune 
Table 1 Phenotype of neoplastic stem cells (NSC) in hematologic neoplasms

\begin{tabular}{|c|c|c|}
\hline Neoplasm & Defined cell subsets containing NSC & Cell surface antigens aberrantly expressed or overexpressed on neoplastic SC \\
\hline AML & CD34+/CD38- [32] & CD25 [75], CD33 [76], CD52[77] \\
\hline \multicolumn{3}{|l|}{ CD96 [68], CD123 [69] } \\
\hline & & CLL-1 [67] \\
\hline AML & CD34+/CD38+ [38] & n.k. \\
\hline $\mathrm{AML}_{\mathrm{NPM} 1 \text { mutated }}$ & CD34- blast-like [78] & n.k. \\
\hline MDS & CD34+ [79] & CD123 [80] \\
\hline MDS with $5 q^{-}$ & CD34+/CD38- [81] & CD52 [77], CD123 \\
\hline MPN & CD34+ [82] & n.k. \\
\hline CML CD123 [86], IL-1RAP [87] & CD34+/CD38- $[17]$ & CD25 [83], CD26 [84], CD33 [85] \\
\hline $\mathrm{Ph}+\mathrm{ALL}$ & CD34+/CD38-/CD19+ [88] & $\mathrm{CD} 25, \mathrm{CD} 26^{\mathrm{a}}, \mathrm{CD} 52$ \\
\hline $\mathrm{Ph}-\mathrm{ALL}$ & CD34+/CD19+ [89] & n.k. \\
\hline CLL & CD34+/CD19+ [90] & CD5 \\
\hline Myeloma & CD20+/CD27+/CD138- [91] & n.k. \\
\hline
\end{tabular}

AML, acute myeloid leukemia; MDS, myelodysplastic syndrome(s); MPN, myeloproliferative neoplasm(s); CML, chronic myeloid leukemia; ALL, acute lymphoblastic leukemia; CLL; chronic lymphocytic leukemia; n.k., not known; NSC, neoplastic stem cells; SC, stem cell; Ph+, Philadelphia chromosome-positive; Ph-, Philadelphia chromosome-negative; IL-1RAP, interleukin-1 receptor accessory protein. ${ }^{a}$ In a subset of patients with Ph + ALL, LSC express CD26.

system of NOD/SCID mice [38]. The problem has been addressed by switching from NOD/SCID mice to NSG (or NOG) mice that lack a functionally active cytokine receptor gamma chain [35-38]. As mentioned above, the lack of a natural immune system in these models is a remaining issue that will hopefully be solved by introducing a humanized immune system into these mice. Another caveat is that some of the antibody preparations used to define CSC may induce apoptosis in cancer cells [74].

In solid tumors, a general problem is that for most neoplasms, robust markers discriminating between more mature and immature cells are not available. In colorectal cancer and some other solid tumors, the Wnt target gene LGR5 has been described as a potential CSC marker [121,122]. Other markers, such as CD44, are broadly expressed on tumor cells and also in other cell types (for example, leukocytes) present in the same organ sites. Another problem is that several CSChoming receptors and their ligands are species specific which may prevent homing of CSC to their specific microenvironment (CSC niche) in mice. Such limitations can be overcame by direct (orthotopic) injection of CSC into target organs or into tissue scaffolds $[39-44,46,123,124]$. Other potential solutions may be to co-transplant 'niche-relevant' autologous (human) stroma cells together with CSC, to treat mice with cytokines promoting the growth of CSC/LSC or to employ NSG mice engineered to express human nicheassociated cytokines such as stem cell factor (SCF) [125]. For the future, mouse models harboring a human immune system as well as human stromal cells might be desirable for studying CSC biology.

Probably the most important problem regarding CSC-recognition is stem cell plasticity and disease heterogeneity $[9,11,25,28,54,126]$. Likewise, depending on the subtype of myeloid leukemia, LSC may reside within the CD34+/CD38- fraction of the clone but also in the CD34+/CD38+ or even in CD34- cell populations $[38,78,126]$. It has also been described that LSC may be composed of CD133+ and CD133- subfractions $[64,127]$. Only a few markers, such as CLL-1 or interleukin-1 receptor accessory protein (IL-1RAP), may be more or less specific for LSC in certain human leukemia models $[67,87]$. These markers are interesting tools and may serve as diagnostic markers or/and therapeutic targets in the future. Tables 1 and 2 show a summary of markers expressed on CSC in hematopoietic neoplasms (Table 1) and non-hematologic malignancies (Table 2).

\section{Regulation of growth and development of CSC/LSC}

So far, little is known about the regulation of growth and survival of CSC/LSC in hematopoietic and nonhematopoietic malignancies. The development phase of CSC may often last for years if not decades $[28,48,54,128]$. In an early phase (pre-phase) of cancer or leukemia development, neoplastic stem cells may be slowly cycling cells that produce small-sized subclones $[11,28,54,128]$. At this early hypothetical stage of cancer evolution, it may be preferable to call these cells premalignant neoplastic stem cells (NSC) rather than CSC/ 
Table 2 Phenotype of CSC-enriched fractions of neoplastic cells in solid tumors ${ }^{\mathrm{a}}$

\begin{tabular}{|c|c|c|}
\hline Neoplasm & Phenotype of CSC-rich cell fraction & Reference \\
\hline \multirow[t]{4}{*}{ Breast cancer } & CD326+/CD45-/CD44+/CD24- & {$[40]$} \\
\hline & CD44+/CD49f+/CD133+ & [92] \\
\hline & CD326+/CD44+/CD47+/MET+ & [93] \\
\hline & CD29f & \\
\hline \multirow[t]{5}{*}{ Gastric cancer } & CD326+/CD44+ & [94] \\
\hline & CD49f+ & [95] \\
\hline & CD90+ & [96] \\
\hline & $\mathrm{LGR5}^{\mathrm{b}}+$ & [97] \\
\hline & CD44+ & [98] \\
\hline \multirow[t]{4}{*}{ Colon cancer } & CD326+/CD44+/CD166+ & [99] \\
\hline & CD44+/CD49f+/CD133+ & {$[100]$} \\
\hline & $\mathrm{LGR}^{\mathrm{b}}+$ & [101] \\
\hline & CD133+ & [47] \\
\hline SCLC & CD133+ & [102] \\
\hline NSCLC & CD133+ & [103] \\
\hline \multirow[t]{2}{*}{ Pancreatic cancer } & CD44+/CD24+/CD326+ & [43] \\
\hline & CD133+/CXCR4+ & [39] \\
\hline \multirow[t]{3}{*}{$\mathrm{HCC}$} & CD326 & [104] \\
\hline & CD133+ & {$[105]$} \\
\hline & CD44+/CD90+ & [44] \\
\hline \multirow[t]{4}{*}{ Glioblastoma } & CD133+ & [42] \\
\hline & CD15+/CD133+ & [106] \\
\hline & CD15+/CD133+ & {$[106]$} \\
\hline & CD133+/SSEA-1+ & [107] \\
\hline Ewing's sarcoma & CD133+ & [108] \\
\hline \multirow[t]{3}{*}{ Osteosarcoma } & CD133+ & [109] \\
\hline & CD117+/STRO-1+ & [110] \\
\hline & CD271+ & [111] \\
\hline \multirow[t]{3}{*}{ Ovarian cancer } & CD24+/CD44+/CD326+ & [112] \\
\hline & CD44+/CD117+ & [113] \\
\hline & CD133+ & [114] \\
\hline \multirow[t]{3}{*}{ Prostate cancer } & CD44+/CD49f/CD326+ & [115] \\
\hline & CD44+/CD24- & [116] \\
\hline & CD44+/CD133+ & [117] \\
\hline \multirow[t]{3}{*}{ Melanoma } & CD271+ & [118] \\
\hline & ABCB5+ & [119] \\
\hline & EPOR+ & {$[120]$} \\
\hline
\end{tabular}

NSC, neoplastic stem cells; LGR5, Leucine-rich repeat-containing G-protein coupled receptor 5; SCLC, small cell lung cancer; n.k., not known; NSCL, nonsmall cell lung cancer; HCC, hepatocellular carcionoma; EPOR, erythropoietin receptor. ${ }^{\mathrm{a}}$ Expression of NSC markers refers to primary human cells tested in xenotransplantation assays and/or in a sphere-formation assay. ${ }^{\mathrm{b}} \mathrm{LGR} 5$ is not detectable on human NSC by flow cytometry.
LSC [24,28,128-131]. Later, when these premalignant cells have accumulated a sufficient number of molecular lesions (defects) and thereby have 'learned' how to escape all relevant surveillance mechanisms, their progeny can expand and form an overt malignancy within short time, so that the term malignant NSC $(=C S C$ or LSC in leukemias) is appropriate $[28,48,128,130,132]$ (Table 3$)$. In early phases of NSC evolution (premalignant stage), the mechanisms and molecules regulating growth, survival, and asymmetrical cell division, may be similar if not the same compared to that in normal stem cells. These factors include cytokines and cytokine-receptors, niche-related factors, including stem cell-homing and chemotactic molecules, pro- and anti-apoptotic molecules, and signaling pathways involved in the regulation of self-renewal and proliferation [133-135]. Later, when NSC-derived neoplastic clones expand to an overt malignancy, several 'physiologic' mechanisms controlling growth and differentiation of normal (and premalignant neoplastic) stem cells may no longer work to prevent clonal expansion [28,48,128,130,136-138].

\section{Cytokine regulation of NSC (CSC/LSC)}

A number of recent data suggest that the cytokine network is involved in the regulation of self-renewal, growth, survival, and differentiation of NSC $[64,69,125]$. As mentioned above, the cytokines that regulate growth and function of premalignant NSC may be similar or the same as that regulating growth of normal stem cells. Likewise, in myeloid leukemias, NSC/LSC express receptors for various regulators of normal stem cells, including the IL-3 receptor (CD123/CD131), SCF receptor KIT (CD117), or G-CSF receptor (CD114) [64,69,139]. It has also been described that epidermal growth factor (EGF) receptor family members, including HER2, are expressed on epithelial NSC/CSC, such as mammary CSC $[140,141]$. There is also evidence that insulin-like growth factor (IGF) receptors and fibroblast growth factor (FGF) receptors play an important role in solid tumors and may be expressed on solid tumor CSC [142-144]. At least in leukemias, the cytokine ligands that bind to these receptors trigger proliferation of LSCenriched cell fractions [139]. Depending on the type and phase of disease, these cytokines also promote differentiation and maturation of LSC. However, most of these cytokines may not cause self-renewal in LSC. Some of these cytokines, such as IL-3, are also produced in clonal cells and may thus act as autocrine growth regulators of LSC $[17,87,145,146]$. LSC are also considered to respond to various chemokines. In line with this assumption, LSC express chemokine receptors such as CXCR4 [39,147-150]. A clinically important question is whether premalignant NSC or CSC/LSC express receptors for erythropoietin (EPO), granulocyte colony-stimulating 
Table 3 Classification of neoplastic stem cells (NSC)

\begin{tabular}{lll}
\hline Defining properties & Premalignant NSC & Malignant NSC = CSC/LSC \\
\hline Self-renewal & Yes & Yes \\
Cell cycle & Dormant or very slowly cycling & Slowly cycling or more rapidly cycling \\
Immediate tumor-initiating potential & No $^{a}$ & Yes \\
Long-term tumor-initiating potential & Facultative potential & Yes \\
Numbers of somatic acquired molecular lesions/ & Relatively low & Relatively high \\
mutations & &
\end{tabular}

Drug response Intrinsic resistance (based in part on

Intrinsic and often also acquired resistance in malignant quiescence) subclones

${ }^{a}$ The potential of a NSC to produce a neoplastic condition does not mean that this cell can form a tumor within a certain time period; however, after a certain latency period, when a sufficient number of molecular lesions have been accumulated, these premalignant NSC may transform to fully malignant NSC (=CSC/LSC) that have immediate tumor-initiating capacity in vivo in patients as well as in NSG mice. In a subset of patients, premalignant NSC will never convert into fully malignant NSC (= CSC/LSC). NSC, neoplastic stem cells; CSC/LSC, cancer stem cells/leukemic stem cells.

factor (G-CSF), or granulocyte/macrophage colonystimulating factor (GM-CSF). These cytokines are often administered in tumor patients in order to correct disease-related anemia or to accelerate neutrophil production after chemotherapy. In AML as well as in the myelodysplastic syndromes (MDS), NSC/LSC indeed express receptors for G-CSF and sometimes also for GMCSF [139]. By contrast, NSC/LSC usually do not express EPO receptors in these malignancies. However, the EPO receptor may be expressed on CSC in a few solid tumors as well as in melanoma-initiating cells [120,151-153]. Table 4 shows a summary of cytokine receptors expressed on CSC and LSC in various malignancies.

\section{Oncogenic signaling pathways in NSC (CSC/LSC)}

Growth and function of NSC, including self-renewal and malignant expansion, are considered to depend on a complex network of signaling cascades and molecules. Oncogenic signaling is considered to derive from three distinct classes of molecules, i) the driver lesions (primary oncogenic kinases) that are often disease-specific or at least disease-related, like $\mathrm{BCR} / \mathrm{ABL}$ in chronic myeloid leukemia (CML), ii) broadly expressed mutated oncogenic kinases, and iii) cytokine-activated stem cell kinases that play a role in survival or/and growth of NSC (example: wt KIT in leukemias). The downstream signaling networks of 'i,' 'ii', and 'iii' are in part

Table 4 Cytokine/chemokine receptors detectable on neoplastic stem cells (NSC)

\begin{tabular}{ll}
\hline Malignancy & Cytokine receptors expressed on NSC \\
\hline AML & IL-2RA [154], IL-3RA [155], G-CSFR [156], FLT3 [157], SCFR/KIT [158], CXCR4 [159] \\
MDS & G-CSFR [160], SCFR/KIT, CXCR4 [161] \\
MPN & G-CSFR [160], SCFR/KIT [162], CXCR4 [163] \\
Ph + CML & IL-2RA [83], IL-3RA [17], G-CSFR [160], GM-CSFR [164], SCFR/KIT [165], IL-1RAP [87], CXCR4 [166] \\
Ph + ALL & IL-2RA [167], IL-3RA [168], CXCR4 [169] \\
Myeloma & CXCR4 [170] \\
Breast cancer & EGFR [171], ERBB2/Her2 [172], FGFR2 [173], TGFßR [174], MET [93] \\
Gastric cancer & EGFR [175], ERBB2/Her2 [176] \\
Colon cancer & EGFR [177], CXCR4 [178], IGF1R [179], TGFßR [180] \\
SCLC & EGFR [181] \\
Pancreatic cancer & EGFR [182], CXCR4 [39] \\
HCC & EGFR, IGF1R [183] \\
Glioblastoma & EGFR [184], PDGFRB [185], CXCR4 [186], TGFßR [187], MET [188] \\
Ovarian cancer & EGFR [189], ERBB2/Her2 [190], IGF1R, TGFBR [191] \\
Prostate cancer & CXCR4 [192] \\
Melanoma & CXCR1 [193], EPOR [120] \\
\hline AML &
\end{tabular}

AML, acute myeloid leukemia; IL, interleukin; G-CSFR, granulocyte colony-stimulating factor receptor; SCF, stem cell factor receptor; Ph+, Philadelphia chromosome-positive; CML, chronic myeloid leukemia; GM-CSF, granulocyte- macrophage colony-stimulating factor; ALL, acute lymphoblastic leukemia; CLL, chronic lymphocytic leukemia; EGFR, epidermal growth factor receptor; TGFßR, transforming growth factor $ß$ receptor; IGF1R, insulin-like growth factor 1 receptor; SCLC, small cell lung cancer; NSCL, non-small cell lung cancer; n.k., not known; HCC, hepatocellular carcionoma; PDGFR, platelet-derived growth factor receptor; NGFR, nerve growth factor receptor; EPOR, erythropoietin receptor. 
overlapping, may often complement each other, and may sometimes even produce synergistic effects on downstream activation and thus oncogenesis [165,194-196]. In an early phase of cancer evolution, the driver mutation ('i') and otherwise physiologic mechanisms ('iii') may play a predominant role. However, with disease progression, more and more additional oncogenic signaling molecules ('ii') and pathways become activated [197-200]. Thus, in advanced phases of a malignancy, additional signaling cascades and networks may play a more and more decisive role in CSC/LSC expansion and resistance. All three classes of molecules may contribute to CSC/LSC resistance, and all three have been considered as potential targets of therapy in solid tumors and leukemias $[7,14,16,28,198,201,202]$.

In the past 15 years, several of the driver kinases have been identified as major targets of therapy. The highlighting example is CML where BCR/ABL-targeting tyrosine kinase inhibitors (TKI) induce major and long-lasting responses [203]. Other similar treatment concepts are emerging in other types of cancers and leukemias as well as in lymphomas. However, it has also been described that in most tumor models, NSC (CSC/LSC) cannot be eradicated completely using these drugs $[11,24,28,130,204]$ as CSC/LSC often grow and survive independent of the primary (major) driver lesion, such as BCR/ABL in CML [204,205].

During the past few years, several major attempts, supported by next-generation sequencing approaches, have been made to reveal additional molecular lesions and the resulting signaling cascades and to define additional target pathways in CSC/LSC [206,207]. Indeed, a number of different signaling pathways - often shared by normal and neoplastic stem cells - have been described to play a role in the evolution and maintenance of CSC/LSC. Several of these pathways have been implicated in stem cell self-renewal. One of these pathways is the $\mathrm{Wnt} / ß$-catenin pathway. This pathway is involved in the maintenance of self-renewal of NSC in leukemias and melanoma as well as in breast, lung, and liver cancers [119,198,208-211]. The Notch signaling pathway has been implicated in selfrenewal of CSC in breast cancer, colon cancer, and glioblastoma [201,212-214]. The hedgehog-signaling pathway is also considered to contribute to self-renewal of CSC in various malignancies, such as glioblastoma, breast cancer, colon cancer, pancreatic cancer, and also in leukemias [215-219]. Other signaling pathways may be involved in the regulation of proliferation, survival, and differentiation of CSC. These pathways include, among others, the PI3 kinasemTOR pathway, the RAS-RAF-MEK-ERK pathway, or the JAK-STAT pathways [196,220-223].

\section{Role of the microenvironment and cell-cell interactions}

Depending on the stage and type of malignancy, growth and self-renewal of NSC (CSC/LSC) rely on a permissive microenvironment, the CSC niche $[4,14,45,72,224,225]$. In an early phase of cancer evolution, the CSC niche may regulate growth and self-renewal of premalignant NSC in a similar or in the same way as that of normal stem cells [54,211-216,226,227]. Relevant molecules contributing to stem cell niche interactions in healthy tissues and in 'premalignant neoplastic states' include adhesion molecules, chemotactic factors, cytokines, and growth factor receptors [99,225,228-235] (Figure 1). In addition, the local electrolyte milieu, the $\mathrm{Ca}^{2+}$ gradient as well as hypoxia may contribute to stem cell niche interactions and stem cell self-renewal in normal and (pre) malignant conditions [225].

\section{Stem cell homing and abnormal spread of NSC/CSC}

Depending on the organ system, homing of stem cells is a physiologic process [225,236-239]. Likewise, normal hematopoietic stem cells are detectable in the peripheral blood and undergo homing in various organs. In most solid organs, however, stem cells do not undergo redistribution and homing, unless these cells transform to metastasizing CSC. Stem cell homing of normal hematopoietic stem cells and LSC is a multi-step process and the same holds true for the invasion-metastasis cascade of CSC [240,241]. Several different molecules are involved in the homing and invasion process, including selectins and selectin-ligands, integrins and their receptors, and other cell-cell and matrix-binding molecules [240,242]. However, ordered expansion and redistribution from and into the stem cell niches in various organs is usually deregulated in premalignant NSC and malignant CSC/LSC [84,99,225,228-235]. In the normal and leukemic bone marrow, several specific molecular interactions that may contribute to stem cell homing (to the niche) have been identified. These include, among others, SDF-1-CXCR4 interactions, SCF-KIT interactions, and Notch-Notch-ligand interactions (Figure 1) $[64,139,225]$. In solid tumors, interactions between CSC and the CSC niche are less well defined. One important type of molecules may be cytoadhesion receptors, including integrins, selectins, CD44, or members of the cadherin family. Most of these homing receptors, including chemokine receptors and ligands of matrix molecules such as L1 or CD44, have been detected on CSC $[228,229,243]$. Likewise, L1 is expressed on the edges of invasive colon cancers and its metastases $[230,231]$ and the same holds true for CD44 and CD133, suggesting that these molecules play a role in tumor invasion and thus disease progression [99,230-232].

During progression of a tumor or leukemia, CSC/LSC may no longer depend on their interaction with the 


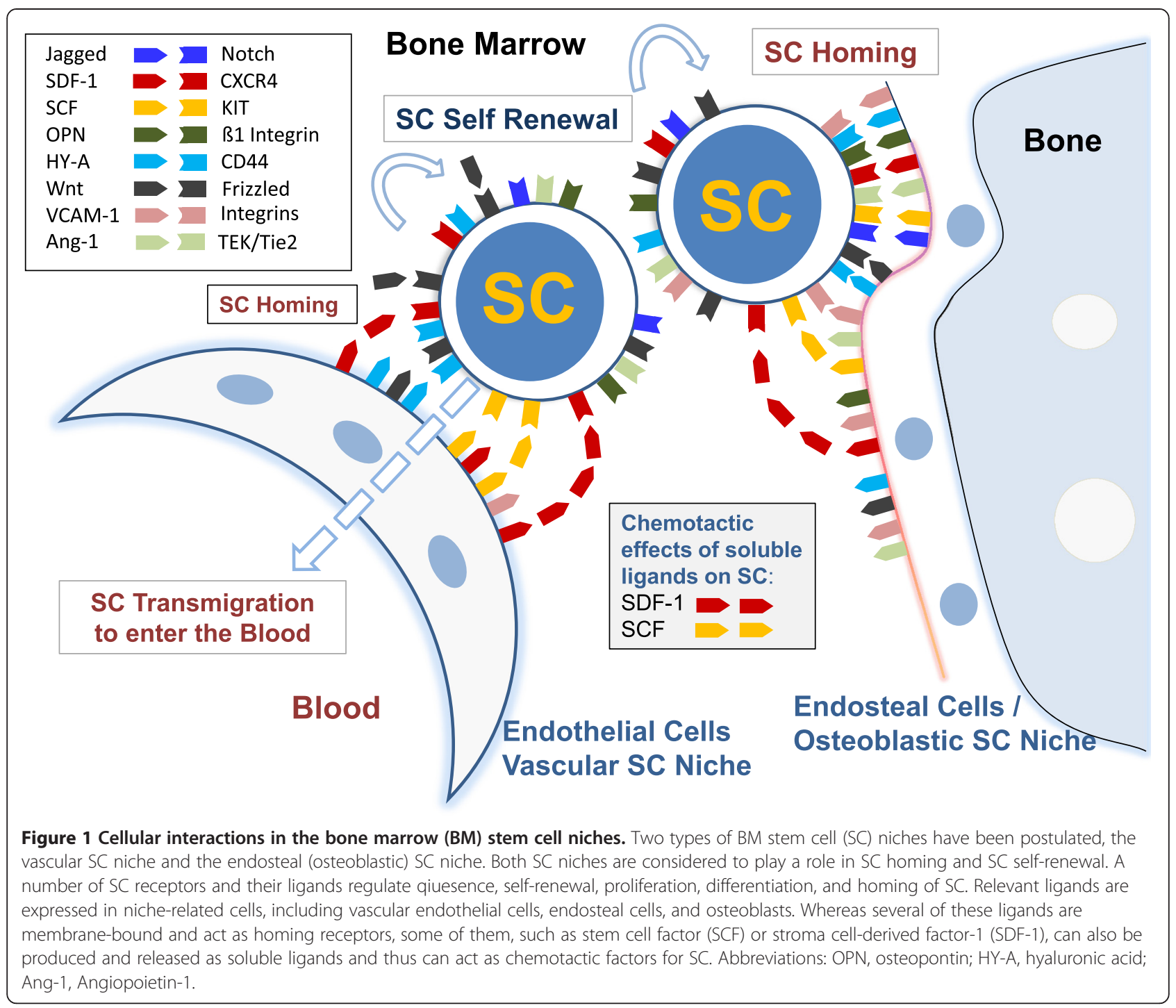

(original) organ-specific microenvironment (CSC niche). Rather, CSC/LSC often expand and redistribute from local sites to other organs to cause metastasis. In epithelial tumors, CSC redistribution is facilitated by the socalled epithelial-mesenchymal transition (EMT), a process that is associated with a loss of specific (adhesive) interactions between cancer cells and the surrounding microenvironment [233,244,245]. Several different molecules, including E-cadherin and L1, have been implicated in the process of EMT in solid tumors [230-233]. Since EMT may also involve CSC, metastasis formation is directly linked to EMT. In hematopoietic neoplasms, similar mechanisms may apply during disease evolution. However, so far, little is known about specific alterations in CSC niche interactions in these malignancies. In CML, LSC have been described to exhibit an adhesion defect that may explain the LSC escape from the bone marrow niche, and subsequent extramedullary spread of progenitors, which is a pathognomonic finding in this type of leukemia $[234,235,246]$.

\section{The endosteal and the vascular stem cell niche in the bone marrow}

In the normal bone marrow (BM) and in hematopoietic neoplasms, two types of stem cell niches have been postulated, a vascular niche and an endosteal (osteoblastic) stem cell niche (Figure 1). Both niches are considered to act together and thereby trigger self-renewal, proliferation, migration, and redistribution of normal and neoplastic (leukemic) stem cells [225,247-249]. Whereas the endosteal niche is considered to regulate self-renewal and quiescence of normal and neoplastic stem cells, the vascular niche is considered to regulate self-renewal, redistribution, and the leukemic spread of these cells. The postulated vascular niche may primarily be composed of endothelial (arterial) cells and perivascular cells, whereas 
the endosteal stem cell niche is primarily represented by endosteal-lining cells and osteoblasts [225,247]. The endosteal niche is considered to provide a more hypoxic and hypercalcemic milieu than the vascular niche, which may also contribute to stem cell niche interactions [14,225,250-252] (Figure 1). Several different adhesion molecules, like hyaluronic acid, Jagged, N-cadherin, osteopontin, CAMs, VEGF, SCF, or SDF-1, are considered to contribute to stem cell homing in the niche [225,247-249]. Normal and neoplastic stem cells express receptors for these stromal ligand receptors (Figure 1).

\section{Role of hypoxia}

Hypoxia and hypoxia-inducible factors (HIF) may influence the fate and self-renewal capacity of stem cells in the micro-milieu of the stem cell niche in health and disease [14,225,250-254]. So far, little is known about the mechanisms through which hypoxia regulates selfrenewal and proliferation of CSC. One important aspect may be that hypoxia upregulates not only HIF expression but also several angiogenic and growth-regulatory cytokines, such as SDF-1 (CXCR4) or VEGF [250, 255,256]. These cytokines may promote tumorassociated angiogenesis. It has also been described that hypoxia maintains a more stem cell-like state of progenitor cells in the BM by regulating key signaling pathways responsible for stem cell growth and survival, such as Notch or Oct4 $[253,254,257,258]$. This may also hold true for CSC/LSC in hypoxic areas in the centers of solid tumors [259]. Another important aspect is that hypoxia can trigger the production of reactive oxygen species (ROS) in neoplastic (stem) cells, which in turn leads to DNA breaks and thereby increases mutagenesis and thus the generation of more malignant subclones $[260,261]$. Thus, hypoxia may be a trigger of oncogenesis and malignant progression as well as CSC/LSC resistance [262-264].

\section{Plasticity and subclone formation of NSC (CSC/LSC)}

A remarkable aspect in the biology of neoplastic stem cells is plasticity and subclone formation during disease evolution which is relevant clinically as subclone formation is often associated with progression and drug resistance. Recent data suggest that in AML and CML, subclone formation is an early and frequent event in LSC development, and the same may hold true for other neoplasms, including solid tumors [26,54,128,129,131 $, 206,220,265]$. Plasticity is best explained by genetic instability. The excessive plasticity and subsequent formation of neoplastic subclones is somehow contradictory to the hypothesis that many (at least premalignant) NSC are quiescent cells. However, subclone formation is now considered to be a step-wise and long-lasting process, which may explain the formation of multiple CSC subclones with varying proliferative capacity (Figure 2) $[28,48,54,128]$. Subclone formation and plasticity of LSC in CML may also be associated with lineage commitment and differentiation or even a lineage switch. One good example is lymphoid or biphenotypic (mixed) blast crisis in $\mathrm{Ph}+\mathrm{CML}$ [266-269]. In rare cases, subclone formation from LSC is excessive and may result in the development of two histologically unrelated but still monoclonal neoplasms [270-272]. Finally, it has also been reported that some of the hematopoietic neoplasms produce their own (clonal) microenvironment [273-275]. A related observation is 'vasculogenic mimicry' that involves the so-called 'malignant stromal cells' or 'malignant endothelial cells.' Such stromal cell progenitors have recently been detected in several malignancies, including AML [276]. All these observations suggest that the leukemia-associated microenvironment, including the LSC niche, is a new emerging target of therapy.

\section{Expression of molecular targets in NSC/CSC}

An essential question in CSC research is whether certain therapeutic targets are expressed in or on CSC. Notably, targeting of CSC using drugs that can kill or permanently suppress these cells may be a pre-requisite for the development of new curative treatment approaches in cancers and leukemias $[7,11,14,16,28]$. However, unfortunately, in many instances, CSC and normal stem cells share the same target antigens [64]. As a result, CSCtargeting therapies often result in the occurrence of substantial adverse side effects such as prolonged cytopenia. In this regard, it is noteworthy that the only available curative drug-therapy in AML, which is polychemotherapy, is usually also associated with prolonged cytopenia. Therefore, current research is seeking novel markers and targets that are preferentially or even selectively expressed on CSC (LSC) but are not expressed (or less abundantly expressed) by normal stem cells $[67,84,87]$.

Examples for surface markers/targets that have been described to be expressed primarily on LSC in myeloid leukemias, but less abundantly (or not at all) on normal stem cells, are CD25, CD26, CD33, CD47, CD52, CD96, CD123, IL-1RAP, and CLL-1 [65-69,72,73,85,277-280]. With regard to CD33 and CD52, clinically established targeting concepts are available [280-282]. Likewise, as assessed by in vitro and in vivo experiments, the CD52targeting antibody alemtuzumab is able to kill LSC in AML and MDS [77]. Figure 3 shows the effect of alemtuzumab on AML LSC in vitro. However, unfortunately, normal stem cells also express low but detectable amounts of these surface antigens, and the respective drugs, gemtuzumab ozogamicin (GO, anti-CD33) and alemtuzumab (anti-CD52) have recently been removed from the oncologic market because of their toxicity profiles which may indeed result in part from their effects 


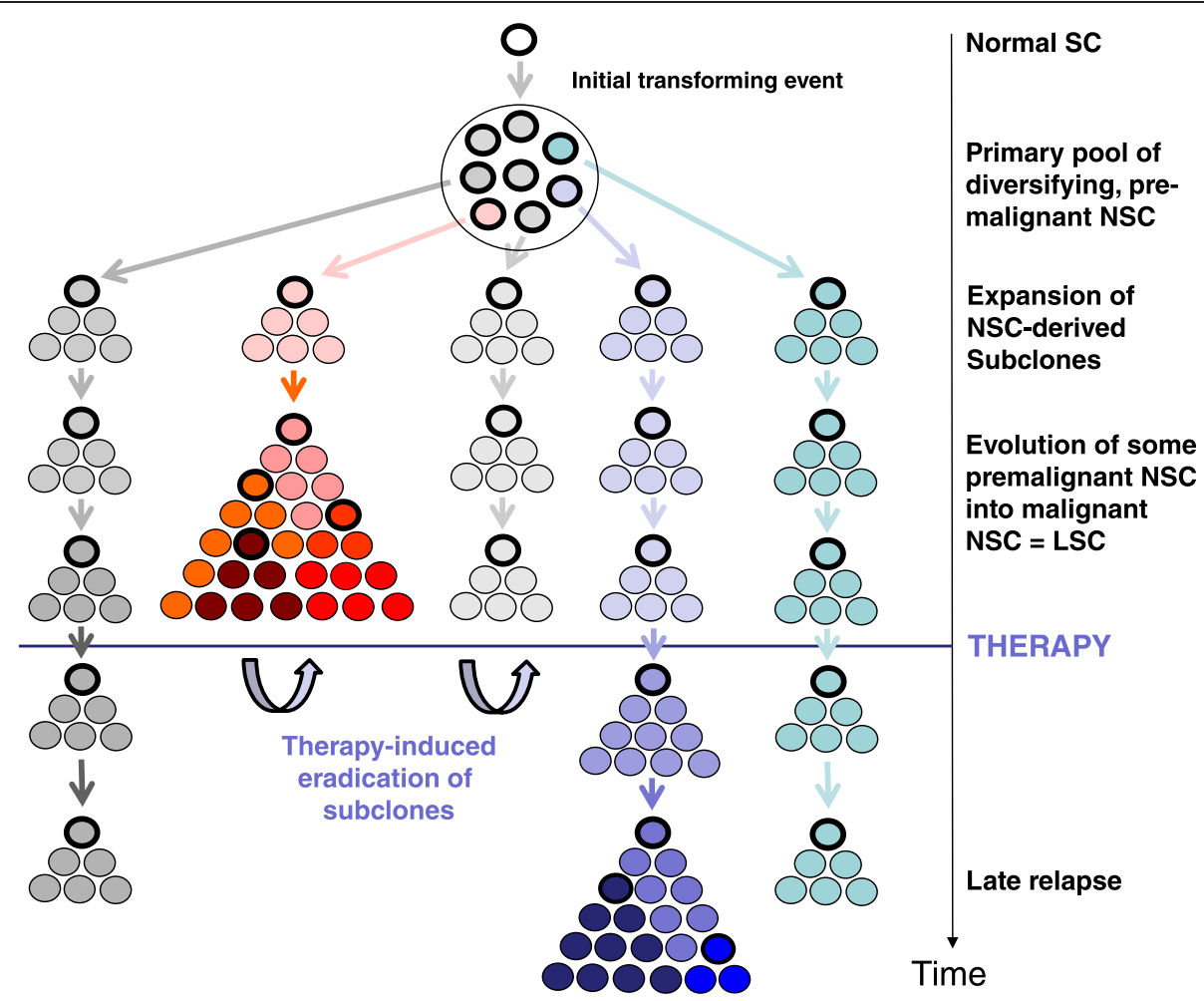

Figure 2 Subclone formation of CSC during evolution of a malignancy. During cancer/leukemia evolution, a large number of different subclones with varying combinations of mutational lesions develop. Each change in color is indicative of the acquisition of a relevant new molecular lesion. After a certain time, one or more malignant (dominant) subclones expand and develop into an overt malignancy. However, at the time of diagnosis of a cancer/leukemia, all the other premalignant subclones and their stem cells are also still present. Neoplastic stem cells are indicated by bold circles. After intensive therapy, many or most (sometimes all) of the cancer/leukemic stem cells may have been eradicated. However, the less malignant (pre-malignant) neoplastic stem cells may still survive (because of their quiescence and other resistance-related mechanisms) and may later expand and produce a relapse. Such late relapses may not necessarily express the same oncogenic lesions (driver mutations) compared to the original subclone but still are derived from the same initial stem cell clone. Today, the subclonal architecture is demonstrable by deep sequencing technologies in various malignancies.

on normal stem cells [280-282]. There are also other antibody-based targeted drugs that are currently being developed, such as (among others) CLL-1, IL-1RAP, CD44, CD96, or CD123. The value of these agents is currently being tested preclinically and in clinical trials [283].

A number of different signaling molecules and survival molecules have been identified as potential targets in LSC/CSC. Among these are the PI3K, mTOR, MEK, Smoothened, Notch, Wnt, heat shock proteins, and Bcl-2 family members. Table 5 provides an overview of molecular targets expressed in CSC and LSC in various malignancies. During the past few years, several potent targeted drugs directed against the primary dominant oncoproteins of various tumors and leukemias have been developed. An interesting example is CML, where BCR/ ABL blockers are applied successfully to suppress the growth and expansion of LSC [203]. However, even BCR/ABL TKI may not be capable of suppressing all LSC for a prolonged time period, because of stem cell resistance [11,19-23,204]. Nevertheless, the effects of BCR/ABL TKI in CML are a highlighting example of LSC suppression. Notably, in many patients in whom TKI treatment has led to a complete continuous molecular response, treatment discontinuation can be performed, and only a subset of these patients relapse whereas others remain BCR/ABL-negative over years, suggesting that many (clinically relevant) LSC had been eradicated [284].

\section{Intrinsic and acquired resistance of NSC/CSC}

Normal and neoplastic stem cells benefit from several repair mechanisms and defense systems through which these cells can escape or survive various stress reactions, toxin-exposure, or microbial attacks, and the same mechanisms are responsible for drug resistance [11,19-23,28,298,299]. In the context of neoplastic stem cells, intrinsic forms and acquired forms of resistance have been described. Intrinsic resistance is usually detectable in all CSC populations (subclones), including 

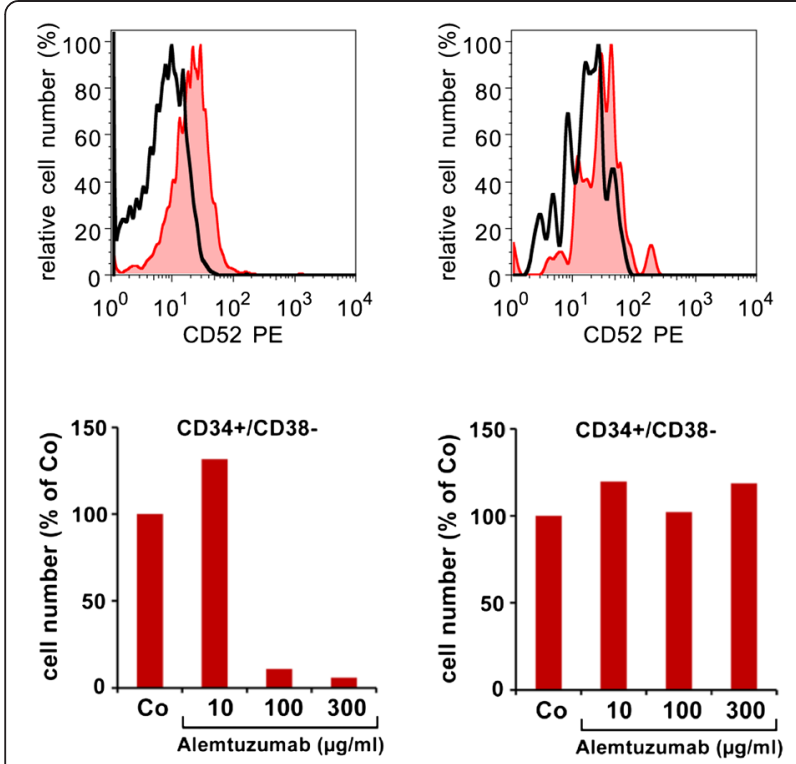

Figure 3 Leukemic stem cells express the cell surface target antigen CD52. Upper panels: bone marrow (BM) cells obtained from a patient with acute myeloid leukemia (AML; left panel) or control BM (right panel) cells were stained with antibodies against CD34, CD38, and CD52. The immature CD34+/CD38- stem cells were found to co-express CD52 (red histogram) in the patient with AML but did not express CD52 in the normal BM. The black open histogram represents the isotype-matched control antibody. Lower panels: BM cells were incubated in various concentrations of the CD52-targeted antibody alemtuzumab at $37^{\circ} \mathrm{C}$ for $1 \mathrm{~h}$. Thereafter, the numbers of viable CD34+/CD38- stem cells were counted by flow cytometry using calibration beads. As visible, exposure to alemtuzumab resulted in a dose-dependent decrease in AML stem cells (left panel) but did not result in a decrease of normal BM stem cells (right panel).

premalignant NSC and CSC/LSC, whereas acquired resistance is usually found in newly generated, more malignant, subclones and their (subclone-specific) CSC/ LSC in advanced neoplasms [11,19-23,298,299].

The mechanisms underlying intrinsic resistance of LSC/CSC are poorly understood. In most neoplasms, multiple factors and mechanisms may act together to produce intrinsic resistance. One factor may be stem cell quiescence [11,19-23,298,299]. Another important factor are cytokine interactions and cell-cell interactions in the CSC niche [14,19-23,28,54]. Moreover, certain drug transporters are expressed differentially in CSC/LSC when compared to more mature neoplastic cells [300-304]. These transporters may mediate drug uptake (such as OCT-1, a drug transporter for Imatinib) but may also contribute to enhanced drug efflux from $\mathrm{CSC} /$ LSC. Likewise, in advanced leukemias, LSC often express MDR-1 and probably other drug efflux transporters [22,300-305]. Similar drug transporters have also been identified in solid tumors and in solid tumor CSC. Other mechanisms underlying intrinsic resistance of LSC/CSC may be an abnormal expression or upregulation of survival-related (stress) molecules (often after drug exposure), abnormal expression of signaling molecules or transcription factors, and the lack or loss of tumor suppressor genes or death regulators [11,19-23,28,41 ,306-312] (Table 6). In addition, the local organ-specific microenvironment, tissue hypoxia, and the interaction with the 'CSC niche' may contribute to the resistance of CSC/LSC [11,19-23,28,45,313].

A number of different mechanisms may underlie acquired drug resistance in CSC/LSC. One is genetic instability and the 'mutation capacity' of the malignant genome, resulting in a plethora of mutations in critical target genes that can be detected in (more) malignant subclones in these patients [28,54,78,129,206,207,325]. These mutations may occur in an early phase (or even prephase) of the disease. They may develop in most, many, or only a few subclones and may either be detectable at diagnosis (prominent subclone/s) or they remain undetectable for a longer time period because they develop in slowly cycling NSC that are only be capable of generating small-sized subclones [26,28,54,128,325]. Nevertheless, as soon as these small-sized subclones acquire a sufficient number of additional hits (mutations), they can expand and develop into an overt disease in which neoplastic cells and CSC exhibit acquired resistance $[26,28,54,128,325]$. The use of targeted drugs must lead to a selection of these more malignant subclones over time. Mutations leading to drug resistance may occur in a number of different genes. Likewise, mutations in various tyrosine kinases may contribute to resistance against oncoprotein-targeting drugs [326-328]. The best studied model is CML, where multiple mutations in the BCR/ABL kinase domains have been identified in Imatinib-treated patients [326-328]. Such mutations have been detected in virtually all oncogenic kinases that play a key role in human leukemogenesis or myeloproliferation and also in most other tumor models [329].

Other mechanisms of acquired resistance include the amplifications of target genes (overexpressed targets) or activation of additional pro-oncogenic molecules (Table 5) [330-334]. These types of resistance are usually associated with a poor prognosis and are often accompanied by cytogenetic evidence of clonal evolution. Likewise, in CML and AML as well as in MDS, a complex karyotype usually indicates an unfavorable prognosis [334-336].

\section{Can we translate the CSC concept into clinical practice?}

Most of the conventional anti-cancer agents currently used in daily practice or in clinical trials are primarily acting on rapidly dividing cells that make up the bulk of the tumor, whereas most CSC (and premalignant NSC) 
Table 5 Molecular targets detectable in neoplastic stem cells (NSC)

\begin{tabular}{|c|c|c|c|}
\hline Target type & Molecular target example & Potentially relevant as NSC-target in & Targeted drug example \\
\hline \multirow[t]{8}{*}{ Surface antigens } & CD20 & $\mathrm{ALL}, \mathrm{CLL}$ & Rituximab $[285,286]$ \\
\hline & CD33 & $\mathrm{CML}, \mathrm{AML}$ & GO $[85,282]$ \\
\hline & CD44 & AML & mAb [72] \\
\hline & CD52 & $5 \mathrm{q}-\mathrm{AML}, \mathrm{CLL}$ & Alemtuzumab $[77,287]$ \\
\hline & CD123 & AML & mAb [69] \\
\hline & EGFR & Colon-Ca & Cetuximab [288] \\
\hline & ERBB2 & Breast/Gastric/ & Trastuzumab [172] \\
\hline & & Ovarian-Ca & \\
\hline \multirow[t]{4}{*}{ Cytokine receptors } & $\mathrm{KIT}$ & GIST, CML & Imatinib $[203,289]$ \\
\hline & PDGFRA & CEL, GIST & Imatinib \\
\hline & EGFR & Pancreas-Ca & Erlotinib [182] \\
\hline & ERBB2 & Breast-Ca & Lapatinib[290] \\
\hline \multirow[t]{5}{*}{ Signaling molecules } & Hedgehog & Basal cell carcinoma & Vismodegib [291] \\
\hline & BRAF & Melanoma & Vemurafenib [292] \\
\hline & BTK & CLL & Ibrutinib [293] \\
\hline & mTOR & Glioblastoma, & Temsirolimus [294,295] \\
\hline & & Renal cell carcinoma & \\
\hline Transcription factors & MYC & AML & JQ1 [296] \\
\hline \multirow[t]{4}{*}{ Niche-NSC-axis } & CD26/DPPIV & CML & Gliptins [84] \\
\hline & CD184/CXCR4- & Plerixafor [159] & \\
\hline & VEGF-VEGFR & - & Bevacizumab [297] \\
\hline & SCF-KIT-axis- & Imatinib [203] & \\
\hline
\end{tabular}

Abbreviations: ALL, acute lymphoblastic leukemia; CLL, chronic lymphocytic leukemia; CML, chronic myeloid leukemia; $\mathrm{AML}$, acute myeloid leukemia; mAb, monoclonal antibodies, EGFR, epidermal growth factor receptor; $\mathrm{Ca}$, carcinoma; GIST, gastrointestinal stroma cell tumor; CEL, chronic eosinophilic leukemia; PDGFR, platelet derived growth factor receptor; BTK, Bruton's tyrosine kinase; mTOR, mammalian target of rapamycin; MDR-1, multidrug-resistance protein 1; CSA, cyclosporine A; DPPIV, dipeptidyl-peptidase IV; VEGF, vascular endothelial growth factor; SCF, stem cell factor.

Table 6 Mechanisms of drug resistance in NSC and strategies to overcome resistance

\begin{tabular}{|c|c|c|}
\hline Mechanism & Proposed strategy to overcame resistance & Examples \\
\hline \multirow[t]{7}{*}{ NSC quiescence } & Antibody-based killing of NSC & CD20, CD33, CD52, \\
\hline & & Bi-specific mAb $[77,280,286]$ \\
\hline & Mobilization of the immune system against NSC & Vaccination [314], \\
\hline & & IL-2 + histamine $[315]$ \\
\hline & NSC mobilization into the cell cycle & Cytokine-priming [316] \\
\hline & CTLA-4 inhibition & Ipilimumab [317] \\
\hline & PD1 inhibition & Nivolumab [318] \\
\hline \multirow[t]{5}{*}{ NSC-niche interactions } & NSC mobilization out of the niche & Plerixafor [159] \\
\hline & Redirection of NSC into the niche & Gliptins (CML [84]) \\
\hline & Targeting of niche cells & Revlimid [319] \\
\hline & Targeting of Niche modulating-cytokines (for example, VEGF) or & Avastin [320] \\
\hline & Cytokine (for example, VEGF) synthesis & Rapamycin [295] \\
\hline Enforced drug efflux Verapamil [321,322] & Blocking the efflux pumps & CSA \\
\hline \multirow[t]{2}{*}{ Expression of anti-apoptotic proteins } & Blocking $\mathrm{BCL}-2$ family members & Obatoclax [323] \\
\hline & Blocking heat shock proteins (Hsp) & Hsp70, Hsp90 [324] \\
\hline
\end{tabular}


are not affected. High-dose chemotherapy and novel targeted drugs may be able to eliminate the bulk of the neoplasm and to eradicate most CSC (or LSC) in a given tumor or leukemia. These debulking agents are still very useful and instrumental in anti-cancer therapy. However, relapses may develop from a few residual, drug-resistant, premalignant (quiescent) NSC that exhibit intrinsic stem cell resistance. Notably, even if all CSC/LSC can be eradicated by drug therapy, (late) relapses can develop from such residual, mostly quiescent premalignant NSC $[26,28,54,128,131,220,325]$. In other words, many new drug therapies can eliminate the mass of CSC/LSC that have generated the dominant clone but are unable to eradicate all quiescent premalignant NSC forming smaller subclones $[26,54,128,284]$. These drugs may even lead to operational cures without having the potential to eradicate the disease completely $[128,284]$. The question is how relevant the residual (often quiescent) NSC are in these patients. Notably, not all types of MRD and MRDspecific NSC may be relevant clinically, even if they may expand to another dominant clone $[28,54,128]$. Likewise, in hairy cell leukemia, cladribine ( $2 \mathrm{CdA})$ may not be able to eradicate all LSC, and most premalignant NSC may survive. However, because of the relatively slow growth rate and low mutation rate of NSC, full blown relapses are relatively uncommon; and if they occur (typically after 3 to 5 years), leukemic cells are again responsive to the same drug. By contrast, in AML, the mutation rate is high and relapses are always indicative of a poor outcome and are often associated with multidrug resistance. The same holds true for most solid tumors. In CML, several novel TKI may induce complete continuous molecular remissions (CMR) [337,338]. Even imatinib can induce long-term CMR in a smaller fraction of patients [284]. When TKI are discontinued in these patients, some of them will relapse but may again respond to imatinib or other new TKI [284]. The exact curative potential of imatinib and of the new TKI in CML remains unknown. In solid tumor, novel TKI have also been applied in clinical trials and some of these agents are rather promising. However, long-term remissions are usually not induced with these agents even when combined with chemotherapy. Overall, with a few exceptions, in most advanced solid tumors, no drug-based CSCeliminating treatment approach has been developed so far. However, there are several examples where targeted drugs as single agents may lead to long-term disease control. One example is the gastrointestinal stroma cell tumors (GIST), where TKI have shown encouraging results [339-341]. Another example is renal cell carcinoma, where inhibitors of the PI3K-mTOR pathway have shown to exert major anti-tumor effects [342,343].

A general problem in cancer evolution is that many CSC/LSC and most or all premalignant NSC may be dormant cells, and that dormancy is often associated with intrinsic resistance. One possible way to overcome this type of resistance may be to apply targeted antibodies, especially antibody-toxin conjugates which often act independent of the cell cycle and thus can destroy even dormant NSC. Likewise, in several types of lymphomas, the addition of pan-B-cell-targeting antibodies has substantially improved cure rates and the overall outcome (survival) in these patients $[287,344,345]$. An alternative strategy is to mobilize dormant cells into the cell cycle or out of the niche (where dormancy may be propagated) [159,346]. Finally, dormancy of NSC/CSC may be overcome by exposure to cytokines that promote cell cycle progression in NSC/CSC. Another principal strategy may be to promote CSC/LSC exhaustion by inducing differentiation and maturation in these cells or by mobilizing the immune system against CSC/LSC.

A major problem is that in advanced cancer lesions, CSC not only exhibit intrinsic (natural) stem cell resistance but often also acquired drug resistance in more resistant and thus more malignant subclones [28,54,128]. One strategy to address the multiple mechanisms of resistance accumulating in advanced tumor lesion is to apply drug combinations. Another strategy is to combine conventional or targeted drugs with response modifiers or agents that mobilize tumor cells into the cell cycle. An alternative approach is to select targeted drugs that can overcome acquired drug resistance resulting from point mutations in critical target genes. Likewise, in CML, second-generation BCR/ABL TKI can often overcome imatinib resistance associated with BCR/ABL mutations $[338,347,348]$.

Another aspect in CSC/LSC evolution is that resistance of CSC/LSC is often associated with specific interactions between these cells and CSC niche. One strategy to overcome this form of resistance is to mobilize CSC/ LSC from the niche where stem cells are considered to be protected and thus less accessible to targeted drugs. One example is the SDF-1/CXCR4 axis that can be disrupted by the CXCR4 blocking agent Plerixafor $[349,350]$. Recent data suggest that Plerixafor cannot only mobilize normal hematopoietic stem cells from the bone marrow stem cell niche but also LSC and that Plerixafor-mobilized LSC may be more sensitive against certain anti-leukemic drugs $[159,346]$. However, it remains unknown whether all LSC can be mobilized by Plerixafor, whether the mobilization is associated with a rebound of more rapidly growing LSC in the niche and whether addition of Plerixafor to conventional chemotherapy will indeed increase response and cure rates in patients with AML or other leukemias. In addition, more recent data suggest that in certain forms of leukemias (CML), LSC are already mobilized cells that can easily traffic between niches [84]. 
Recent data suggest that the vascular (arteriolar) stem cell niche is of particular importance for self-renewal of LSC [225,247-249]. Therefore, additional effects of targeted drugs on vascular cells or drug combinations employing anti-angiogenic agents are of considerable interest. One of these anti-angiogenic drugs is Lenalidomide, a major anti-angiogenic drug that produces major responses in various myeloid and lymphoid neoplasms, including 5q-MDS, multiple myeloma, and chronic lymphocytic leukemia. Several other anti-angiogenic drugs have been tested in hematopoietic and solid malignancies, with varying success. Encouraging results have been obtained when combining these agents with other anti-neoplastic agents. A remarkable observation is that the novel BCR/ABL TKI Nilotinib and Ponatinib (but not imatinib) are potent inhibitors of endothelial growth and angiogenesis [351]. Whether these additional effects of these TKI are responsible for their better efficacy in CML remains unknown. This is an attractive hypothesis, since their much stronger effects on BCR/ABL (when compared to imatinib) fail to explain their excellent clinical efficacy, as CML LSC are considered to survive independent of BCR/ABL [352,353]. Table 6 provides strategies aimed at overcoming LSC resistance in human malignancies.

\section{Summary and future perspectives}

During the past few years several CSC/LSC-targeting concepts have been developed with the aim to establish more effective treatment approaches in applied oncology. However, although such novel treatment concepts are straight-forward, several questions remain. First, the complexity of the somatic aberration networks and of the resulting signaling cascades that drive oncogenesis during CSC/LSC evolution and may lead to CSC/ LSC resistance. To address this aspect, the use of drug combinations or broadly acting drugs has been suggested and may be required to eliminate or suppress all relevant CSC/LSC populations in a given neoplasm. Novel treatment concepts have to take additional aspects into account, including intrinsic resistance, the related issue of CSC/LSC quiescence, and the interaction of CSC/LSC with their organ- and diseasespecific microenvironment (CSC niche). Additional local factors such as hypoxia may also play a role in CSC/LSC resistance. The hope for the future is that we will be able to exploit our increasing knowledge about CSC/LSC, in order to define new treatment concepts, with the ultimate aim to eradicate CSC/LSC in various cancer types as well as in leukemias. In advanced, drugresistant neoplasms, such treatment concepts may need to be combined with high-dose chemotherapy and/or stem cell transplantation.

\section{Abbreviations}

BM: bone marrow; CD: cluster of differentiation; CML: chronic myeloid leukemia; CSC: cancer stem cell(s); CXCR-4: C-X-C chemokine receptor type 4; EMT: epithelial-mesenchymal transition; FGF: fibroblast growth factor; G-CSF: granulocyte colony-stimulating factor; GM-CSF: granulocytemacrophage colony-stimulating factor; Her 2: human epidermal growth factor receptor 2; IL: interleukin; LSC: leukemic stem cell(s); NOD/SCID: non-obese diabetic mice with severe combined immunodeficiency; NOG: IL-2Rgamma chain-knock out NOD/shi-SCID mice; NSC: neoplastic stem cell (s); NSG: NOD/SCID with loss-of-function-mutated IL-2Rgamma chain; PI3K: phosphatidylinositide-3 kinase; SCF: stem cell factor; SDF-1: stromal cell-derived factor 1; TKI: tyrosine kinase inhibitor(s).

\section{Competing interests}

The authors declare that they have no competing interests.

\section{Authors' contributions}

AS, BM, TWG, CCZ, and PV drafted the manuscript. KB, SC-R, IS, and HH helped to design the draft and provided figures and tables. All authors read and approved the final manuscript.

\section{Funding}

This study was supported by the Austrian Science Funds, Project SFB-F4704B20\#, a cancer stem cell grant of the Medical University of Vienna and a research grant of the Initiative Krebsforschung Vienna, Austria.

\section{Author details}

${ }^{1}$ Bone Marrow Transplantation Unit, Department of Internal Medicine I, Medical University of Vienna, Währinger Gürtel 18-20, Vienna A-1090, Wien, Austria. ${ }^{2}$ Ludwig Boltzmann Cluster Oncology, Medical University of Vienna, Spitalgasse 23, Vienna 1090, Wien, Austria. ${ }^{3}$ Department of Medicine I, Division of Hematology and Hemostaseology, Medical University of Vienna, Währinger Gürtel 18-20, Vienna 1090, Wien, Austria. ${ }^{4}$ Department of Radiation Therapy, Medical University of Vienna, Spitalgasse 23, Vienna 1090, Wien, Austria. ${ }^{5}$ Department of Medicine I, Institute for Cancer Research, Medical University of Vienna, Währinger Gürtel 18-20, Vienna 1090, Wien, Austria. ${ }^{6}$ Department of Medicine I, Division of Clinical Oncology, Medical University of Vienna, Währinger Gürtel 18-20, Vienna 1090, Wien, Austria.

${ }^{7}$ Department of Medicine I, Stem Cell Transplantation Unit, Medical

University of Vienna, Waehringer Guertel 18-20, A-1090 Wien, Austria.

Received: 15 October 2014 Accepted: 14 January 2015

Published online: 25 February 2015

\section{References}

1. Reya T, Morrison SJ, Clarke MF, Weissman IL. Stem cells, cancer, and cancer stem cells. Nature. 2001;414:105-11.

2. Ailles LE, Weissman IL. Cancer stem cells in solid tumors. Curr Opin Biotechnol. 2007:18:460-6.

3. Dalerba P, Cho RW, Clarke MF. Cancer stem cells: models and concepts. Annu Rev Med. 2007;58:267-84

4. Calabrese C, Poppleton H, Kocak M, Hogg TL, Fuller C, Hamner B, et al. A perivascular niche for brain tumor stem cells. Cancer Cell. 2007;11:69-82.

5. Dick JE. Stem cell concepts renew cancer research. Blood. 2008;112:4793-807.

6. Cho RW, Clarke MF. Recent advances in cancer stem cells. Curr Opin Genet Dev. 2008;18:48-53.

7. Schatton T, Frank NY, Frank MH. Identification and targeting of cancer stem cells. Bioessays. 2009;31:1038-49.

8. Schulenburg A, Bramswig K, Herrmann H, Karlic H, Mirkina I, Hubmann R, et al. Neoplastic stem cells: current concepts and clinical perspectives. Crit Rev Oncol Hematol. 2010;76:79-98.

9. Greaves M. Cancer stem cells: back to Darwin? Semin Cancer Biol. 2010;20 (2):65-70.

10. Clarke MF, Dick JE, Dirks PB, Eaves CJ, Jamieson CH, Jones DL, et al. Cancer stem cells - perspectives on current status and future directions: AACR Workshop on cancer stem cells. Cancer Res. 2006;66:9339-44.

11. Valent P. Emerging stem cell concepts for imatinib-resistant chronic myeloid leukaemia: implications for the biology, management, and therapy of the disease. Br J Haematol. 2008;142(3):361-78. 
12. Dick JE, Lapidot T. Biology of normal and acute myeloid leukemia stem cells. Int J Hematol. 2005:82:389-96.

13. Hope KJ, Jin L, Dick JE. Acute myeloid leukemia originates from a hierarchy of leukemic stem cell classes that differ in self-renewal capacity. Nat Immunol. 2004;5:738-43.

14. Konopleva MY, Jordan CT. Leukemia stem cells and microenvironment: biology and therapeutic targeting. J Clin Oncol. 2011;29:591-9.

15. Sloma I, Jiang $X$, Eaves AC, Eaves CJ. Insights into the stem cells of chronic myeloid leukemia. Leukemia. 2010;24:1823-33.

16. Roboz GJ, Guzman M. Acute myeloid leukemia stem cells: seek and destroy. Expert Rev Hematol. 2009;2:663-72.

17. Holyoake TL, Jiang X, Jorgensen HG, Graham S, Alcorn MJ, Laird C, et al. Primitive quiescent leukemic cells from patients with chronic myeloid leukemia spontaneously initiate factor-independent growth in vitro in association with up-regulation of expression of interleukin-3. Blood. 2001;97:720-8

18. Copland M. Chronic myelogenous leukemia stem cells: what's new? Curr Hematol Malig Rep. 2009;4:66-73.

19. Singh A, Settleman J. EMT, cancer stem cells and drug resistance: an emerging axis of evil in the war on cancer. Oncogene. 2010;29:4741-51.

20. Donnenberg VS, Donnenberg AD. Multiple drug resistance in cancer revisited: the cancer stem cell hypothesis. J Clin Pharmacol. 2005;45:872-7.

21. Dean M, Fojo T, Bates S. Tumour stem cells and drug resistance. Nat Rev Cancer. 2005;5:275-84

22. Jiang $X$, Zhao Y, Smith C, Gasparetto M, Turhan A, Eaves A, et al. Chronic myeloid leukemia stem cells possess multiple unique features of resistance to BCR-ABL targeted therapies. Leukemia. 2007;21:926-35.

23. Barnes DJ, Melo JV. Primitive, quiescent and difficult to kill: the role of non-proliferating stem cells in chronic myeloid leukemia. Cell Cycle. 2006;5:2862-6.

24. Welch JS. Mutation position within evolutionary subclonal architecture in AML. Semin Hematol. 2014;51:273-83.

25. Wang $M$, Wang $Y$, Zhong J. Side population cells and drug resistance in breast cancer. Mol Med Rep. 2015;doi:10.3892/mmr.2015.3291.

26. Preuner S, Mitterbauer G, Mannhalter C, Herndlhofer S, Sperr WR, Valent $P$, et al. Quantitative monitoring of BCR/ABL1 mutants for surveillance of subclone-evolution, -expansion, and -depletion in chronic myeloid leukaemia. Eur J Cancer. 2012:48:233-6.

27. Schatton T, Murphy GF, Frank NY, Yamaura K, Waaga-Gasser AM, Gasser M, et al. Identification of cells initiating human melanomas. Nature. 2008;451:345-9.

28. Valent P. Targeting of leukemia-initiating cells to develop curative drug therapies: straightforward but nontrivial concept. Curr Cancer Drug Targets. 2011;11(1):56-71.

29. Frank NY, Schatton T, Frank MH. The therapeutic promise of the cancer stem cell concept. J Clin Invest. 2010;120:41-50.

30. Besancon R, Valsesia-Wittmann S, Puisieux A, de Fromentel CC, MaguerSatta V. Cancer stem cells: the emerging challenge of drug targeting. Curr Med Chem. 2009;16:394-416.

31. Korkaya H, Wicha MS. Selective targeting of cancer stem cells: a new concept in cancer therapeutics. BioDrugs. 2007:21:299-310.

32. Bonnet D, Dick JE. Human acute myeloid leukemia is organized as a hierarchy that originates from a primitive hematopoietic cell. Nat Med. 1997;3:730-7.

33. Lapidot T, Sirard C, Vormoor J, Murdoch B, Hoang T, Caceres-Cortes J, et al, A cell initiating human acute myeloid leukaemia after transplantation into SCID mice. Nature. 1994;367:645-8.

34. Civenni G, Walter A, Kobert N, Mihic-Probst D, Zipser M, Belloni B, et al. Human CD271-positive melanoma stem cells associated with metastasis establish tumor heterogeneity and long-term growth. Cancer Res. 2011;71:3098-109.

35. Pearson T, Greiner DL, Shultz LD. Creation of "humanized" mice to study human immunity. Curr Protoc Immunol. 2008;15(15):21.

36. Ishikawa F, Saito Y, Yoshida S, Harada M, Shultz LD. The differentiative and regenerative properties of human hematopoietic stem/progenitor cells in NOD-SCID/IL2rgamma(null) mice. Curr Top Microbiol Immunol. 2008;324:87-94.

37. Quintana E, Shackleton M, Sabel MS, Fullen DR, Johnson TM, Morrison SJ. Efficient tumour formation by single human melanoma cells. Nature. 2008:456:593-8.

38. Taussig DC, Miraki-Moud F, Anjos-Afonso F, Pearce DJ, Allen K, Ridler C, et al. Anti-CD38 antibody-mediated clearance of human repopulating cells masks the heterogeneity of leukemia-initiating cells. Blood. 2008;112:568-75.
39. Hermann PC, Huber SL, Herrler T, Aicher A, Ellwart JW, Guba M, et al Distinct populations of cancer stem cells determine tumor growth and metastatic activity in human pancreatic cancer. Cell Stem Cell. 2007;1:313-23.

40. Al-Hajj M, Wicha MS, Benito-Hernandez A, Morrison SJ, Clarke MF. Prospective identification of tumorigenic breast cancer cells. Proc Natl Acad Sci U S A. 2003;100:3983-8

41. Bao S, Wu Q, McLendon RE, Hao Y, Shi Q, Hjelmeland AB, et al. Glioma stem cells promote radioresistance by preferential activation of the DNA damage response. Nature. 2006:444:756-60.

42. Singh SK, Hawkins C, Clarke ID, Squire JA, Bayani J, Hide T, et al. Identification of human brain tumour initiating cells. Nature. 2004:432:396-401.

43. Li C, Heidt DG, Dalerba P, Burant CF, Zhang L, Adsay V, et al. Identification of pancreatic cancer stem cells. Cancer Res. 2007;67:1030-7.

44. Yang ZF, Ho DW, Ng MN, Lau CK, Yu WC, Ngai P, et al. Significance of CD90 + cancer stem cells in human liver cancer. Cancer Cell. 2008;13:153-66.

45. Ishikawa F, Yoshida S, Saito Y, Hijikata A, Kitamura H, Tanaka S, et al. Chemotherapy-resistant human AML stem cells home to and engraft within the bone-marrow endosteal region. Nat Biotechnol. 2007;25:1315-21.

46. O'Brien CA, Pollett A, Gallinger S, Dick JE. A human colon cancer cell capable of initiating tumour growth in immunodeficient mice. Nature. 2007:445:106-10

47. Ricci-Vitiani L, Lombardi DG, Pilozzi E, Biffoni M, Todaro M, Peschle C, et al. Identification and expansion of human colon-cancer-initiating cells. Nature. 2007:445:111-5.

48. Bohm A, Herrmann H, Mitterbauer-Hohendanner G, Hauswirth AW, Rabitsch W, Mitterbauer $M$, et al. Stable non-transforming minimal residual disease in Philadelphia chromosome positive acute lymphoblastic leukemia after autologous transplantation: origin from neoplastic yet 'pre-leukemic' stem cells? Leuk Lymphoma. 2011;52:842-8

49. Dontu G, Abdallah WM, Foley JM, Jackson KW, Clarke MF, Kawamura MJ, et al. In vitro propagation and transcriptional profiling of human mammary stem/progenitor cells. Genes Dev. 2003;17:1253-70.

50. Fang D, Nguyen TK, Leishear K, Finko R, Kulp AN, Hotz S, et al. A tumorigenic subpopulation with stem cell properties in melanomas. Cancer Res. 2005;65:9328-37.

51. Dexter TM, Allen TD, Lajtha LG. Conditions controlling the proliferation of haemopoietic stem cells in vitro. J Cell Physiol. 1977;91:335-44.

52. Hemmati HD, Nakano I, Lazareff JA, Masterman-Smith M, Geschwind DH, Bronner-Fraser $M$, et al. Cancerous stem cells can arise from pediatric brain tumors. Proc Natl Acad Sci U S A. 2003;100:15178-83.

53. Vermeulen L, Todaro M, de Sousa MF, Sprick MR, Kemper K, Perez Alea M, et al. Single-cell cloning of colon cancer stem cells reveals a multi-lineage differentiation capacity. Proc Natl Acad Sci U S A. 2008;105:13427-32.

54. Gerashchenko BI, Huna A, Erenpreisa J. Characterization of breast cancer DNA content profiles as a prognostic tool. Exp Oncol. 2014;36:219-25.

55. Moserle L, Ghisi M, Amadori A, Indraccolo S. Side population and cancer stem cells: therapeutic implications. Cancer Lett. 2010;288:1-9.

56. Fukaya R, Ohta S, Yamaguchi M, Fujii H, Kawakami Y, Kawase T, et al. Isolation of cancer stem-like cells from a side population of a human glioblastoma cell line, SK-MG-1. Cancer Lett. 2010;291:150-7.

57. Murase M, Kano M, Tsukahara T, Takahashi A, Torigoe T, Kawaguchi S, et al. Side population cells have the characteristics of cancer stem-like cells/ cancer-initiating cells in bone sarcomas. Br J Cancer. 2009;101:1425-32.

58. Li T, Su Y, Mei Y, Leng Q, Leng B, Liu Z, et al. ALDH1A1 is a marker for malignant prostate stem cells and predictor of prostate cancer patients' outcome. Lab Invest. 2010:90:234-44.

59. Ran D, Schubert M, Pietsch L, Taubert I, Wuchter P, Eckstein V, et al. Aldehyde dehydrogenase activity among primary leukemia cells is associated with stem cell features and correlates with adverse clinical outcomes. Exp Hematol. 2009;37:1423-34.

60. Chen YC, Chen YW, Hsu HS, Tseng LM, Huang PI, Lu KH, et al. Aldehyde dehydrogenase 1 is a putative marker for cancer stem cells in head and neck squamous cancer. Biochem Biophys Res Commun. 2009;385:307-13.

61. Moreb JS. Aldehyde dehydrogenase as a marker for stem cells. Curr Stem Cell Res Ther. 2008;3:237-46.

62. Polyak K, Hahn WC. Roots and stems: stem cells in cancer. Nat Med. 2006;12:296-300.

63. Weissman IL, Shizuru JA. The origins of the identification and isolation of hematopoietic stem cells, and their capability to induce donor-specific 
transplantation tolerance and treat autoimmune diseases. Blood 2008;112:3543-53.

64. Florian S, Sonneck K, Hauswirth AW, Krauth MT, Schernthaner GH, Sperr WR, et al. Detection of molecular targets on the surface of CD34+/CD38- stem cells in various myeloid malignancies. Leuk Lymphoma. 2006;47:207-22.

65. Moshaver B, van Rhenen A, Kelder A, van der Pol M, Terwijn M, Bachas C, et al. Identification of a small subpopulation of candidate leukemia initiating cells in the side population (SP) of patients with acute myeloid leukemia. Stem Cells. 2008;26(12):3059-67.

66. Blair A, Hogge DE, Ailles LE, Lansdorp PM, Sutherland HJ. Lack of expression of Thy-1 (CD90) on acute myeloid leukemia cells with long-term proliferative ability in vitro and in vivo. Blood. 1997;89:3104-12.

67. van Rhenen A, van Dongen GA, Kelder A, Rombouts EJ, Feller N, Moshaver $B$, et al. The novel AML stem cell associated antigen CLL-1 aids in discrimination between normal and leukemic stem cells. Blood. 2007;110:2659-66.

68. Hosen N, Park CY, Tatsumi N, Oji Y, Sugiyama H, Gramatzki M, et al. CD96 is a leukemic stem cell-specific marker in human acute myeloid leukemia. Proc Natl Acad Sci U S A. 2007;104:11008-13.

69. Jordan CT, Upchurch D, Szilvassy SJ, Guzman ML, Howard DS, Pettigrew AL, et al. The interleukin-3 receptor alpha chain is a unique marker for human acute myelogenous leukemia stem cells. Leukemia. 2000;14:1777-84.

70. Fina L, Molgaard HV, Robertson D, Bradley NJ, Monaghan P, Delia D, et al. Expression of the CD34 gene in vascular endothelial cells. Blood. 1990;75:2417-26.

71. Kitamura Y, Hirotab S. Kit as a human oncogenic tyrosine kinase. Cell Mol Life Sci. 2004;61:2924-31

72. Jin L, Hope KJ, Zhai Q, Smadja-Joffe F, Dick JE. Targeting of CD44 eradicates human acute myeloid leukemic stem cells. Nat Med. 2006;12:1167-74.

73. Majeti R, Chao MP, Alizadeh AA, Pang WW, Jaiswal S, Gibbs Jr KD, et al CD47 is an adverse prognostic factor and therapeutic antibody target on human acute myeloid leukemia stem cells. Cell. 2009;138:286-99.

74. Kim JB, Ko E, Han W, Lee JE, Lee KM, Shin I, et al. CD24 cross-linking induces apoptosis in, and inhibits migration of, MCF-7 breast cancer cells. BMC Cancer. 2008:8:118

75. Saito Y, Kitamura H, Hijikata A, Tomizawa-Murasawa M, Tanaka S, Takagi S, et al. Identification of therapeutic targets for quiescent, chemotherapyresistant human leukemia stem cells. Sci Transl Med. 2010;2:17ra19.

76. Taussig DC, Pearce DJ, Simpson C, Rohatiner AZ, Lister TA, Kelly G, et al. Hematopoietic stem cells express multiple myeloid markers: implications for the origin and targeted therapy of acute myeloid leukemia. Blood. 2005;106:4086-92

77. Blatt K, Herrmann H, Hoermann G, Willmann M, Cerny-Reiterer S, Sadovnik I, et al. Identification of campath-1 (CD52) as novel drug target in neoplastic stem cells in 5q-patients with MDS and AML. Clin Cancer Res. 2014;20 (13):3589-602.

78. Taussig DC, Vargaftig J, Miraki-Moud F, Griessinger E, Sharrock K, Luke T, et al. Leukemia-initiating cells from some acute myeloid leukemia patients with mutated nucleophosmin reside in the CD34(-) fraction. Blood. 2010;115:1976-84.

79. Nilsson L, Astrand-Grundstrom I, Anderson K, Arvidsson I, Hokland P, Bryde D, et al. Involvement and functional impairment of the CD34(+)CD38(-) Thy-1(+) hematopoietic stem cell pool in myelodysplastic syndromes with trisomy 8. Blood. 2002;100:259-67.

80. De Smet D, Trullemans F, Jochmans K, Renmans W, Smet L, Heylen O, et al Diagnostic potential of CD34+ cell antigen expression in myelodysplastic syndromes. Am J Clin Pathol. 2012;138:732-43.

81. Nilsson L, Astrand-Grundstrom I, Arvidsson I, Jacobsson B, HellstromLindberg E, Hast R, et al. Isolation and characterization of hematopoietic progenitor/stem cells in 5q-deleted myelodysplastic syndromes: evidence for involvement at the hematopoietic stem cell level. Blood. 2000;96:2012-21.

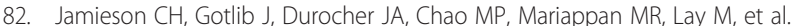
The JAK2 V617F mutation occurs in hematopoietic stem cells in polycythemia vera and predisposes toward erythroid differentiation. Proc Natl Acad Sci U S A. 2006;103:6224-9.

83. Kobayashi Cl, Takubo K, Kobayashi H, Nakamura-lshizu A, Honda H, Kataoka $K$, et al. The IL-2/CD25 axis maintains distinct subsets of chronic myeloid leukemia-initiating cells. Blood. 2014;123:2540-9.

84. Herrmann H, Sadovnik I, Cerny-Reiterer S, Rulicke T, Stefanzl G, Willmann M, et al. Dipeptidylpeptidase IV (CD26) defines leukemic stem cells (LSC) in chronic myeloid leukemia. Blood. 2014;123(25):3951-62.
85. Herrmann H, Cerny-Reiterer S, Gleixner KV, Blatt K, Herndlhofer S, Rabitsch W, et al. CD34(+)/CD38(-) stem cells in chronic myeloid leukemia express Siglec-3 (CD33) and are responsive to the CD33-targeting drug gemtuzumab/ozogamicin. Haematologica. 2012;97:219-26.

86. Nievergall E, Ramshaw HS, Yong AS, Biondo M, Busfield SJ, Vairo G, et al. Monoclonal antibody targeting of IL-3 receptor alpha with CSL362 effectively depletes CML progenitor and stem cells. Blood. 2014;123:1218-28.

87. Jaras M, Johnels $\mathrm{P}$, Hansen $\mathrm{N}$, Agerstam $\mathrm{H}$, Tsapogas $\mathrm{P}$, Rissler $\mathrm{M}$, et al. Isolation and killing of candidate chronic myeloid leukemia stem cells by antibody targeting of IL-1 receptor accessory protein. Proc Natl Acad Sci U S A. 2010;107:16280-5

88. Cobaleda C, Gutierrez-Cianca N, Perez-Losada J, Flores T, Garcia-Sanz R, Gonzalez M, et al. A primitive hematopoietic cell is the target for the leukemic transformation in human philadelphia-positive acute lymphoblastic leukemia. Blood. 2000;95:1007-13.

89. Kong Y, Yoshida S, Saito Y, Doi T, Nagatoshi Y, Fukata M, et al. CD34 + CD38 + CD19+ as well as CD34 + CD38-CD19+ cells are leukemia-initiating cells with self-renewal capacity in human B-precursor ALL. Leukemia. 2008;22:1207-13

90. Rossi FM, Zucchetto A, Tissino E, Dal Bo M, Bomben R, Caldana C, et al. CD49d expression identifies a chronic-lymphocytic leukemia subset with high levels of mobilized circulating CD34(+) hemopoietic progenitors cells. Leukemia. 2014;28:705-8.

91. Matsui W, Wang Q, Barber JP, Brennan S, Smith BD, Borrello I, et al Clonogenic multiple myeloma progenitors, stem cell properties, and drug resistance. Cancer Res. 2008;68:190-7.

92. Meyer MJ, Fleming JM, Lin AF, Hussnain SA, Ginsburg E, Vonderhaar BK. CD44posCD49fhiCD133/2hi defines xenograft-initiating cells in estrogen receptor-negative breast cancer. Cancer Res. 2010;70:4624-33.

93. Baccelli I, Schneeweiss A, Riethdorf S, Stenzinger A, Schillert A, Vogel V, et al. Identification of a population of blood circulating tumor cells from breast cancer patients that initiates metastasis in a xenograft assay. Nat Biotechnol. 2013;31:539-44.

94. Han ME, Jeon TY, Hwang SH, Lee YS, Kim HJ, Shim HE, et al. Cancer spheres from gastric cancer patients provide an ideal model system for cancer stem cell research. Cell Mol Life Sci. 2011;68:3589-605.

95. Fukamachi H, Seol HS, Shimada S, Funasaka C, Baba K, Kim JH, et al. CD49f (high) cells retain sphere-forming and tumor-initiating activities in human gastric tumors. PLoS One. 2013;8:e72438.

96. Jiang J, Zhang Y, Chuai S, Wang Z, Zheng D, Xu F, et al. Trastuzumab (herceptin) targets gastric cancer stem cells characterized by CD90 phenotype. Oncogene. 2012;31:671-82.

97. Jang BG, Lee BL, Kim WH. Distribution of LGR5+ cells and associated implications during the early stage of gastric tumorigenesis. PLoS One 2013:8:e82390

98. Takaishi S, Okumura T, Tu S, Wang SS, Shibata W, Vigneshwaran R, et al. Identification of gastric cancer stem cells using the cell surface marker CD44. Stem Cells. 2009;27:1006-20.

99. Dalerba P, Dylla SJ, Park IK, Liu R, Wang X, Cho RW, et al. Phenotypic characterization of human colorectal cancer stem cells. Proc Natl Acad Sci U S A. 2007;104:10158-63.

100. Haraguchi N, Ishii H, Mimori K, Ohta K, Uemura M, Nishimura J, et al. CD49fpositive cell population efficiently enriches colon cancer-initiating cells. Int J Oncol. 2013:43:425-30

101. Barker N, van Es JH, Kuipers J, Kujala P, van den Born M, Cozijnsen M, et al. Identification of stem cells in small intestine and colon by marker gene Lgr5. Nature. 2007:449:1003-7.

102. Eramo A, Lotti F, Sette G, Pilozzi E, Biffoni M, Di Virgilio A, et al. Identification and expansion of the tumorigenic lung cancer stem cell population. Cell Death Differ. 2008;15:504-14.

103. Tirino V, Camerlingo R, Franco R, Malanga D, La Rocca A, Viglietto G, et al. The role of CD133 in the identification and characterisation of tumour-initiating cells in non-small-cell lung cancer. Eur J Cardiothorac Surg. 2009;36(3):446-53.

104. Yamashita T, Ji J, Budhu A, Forgues M, Yang W, Wang HY, et al. EpCAMpositive hepatocellular carcinoma cells are tumor-initiating cells with stem/ progenitor cell features. Gastroenterology. 2009;136:1012-24.

105. Ma S, Lee TK, Zheng BJ, Chan KW, Guan XY. CD133+ HCC cancer stem cells confer chemoresistance by preferential expression of the Akt/PKB survival pathway. Oncogene. 2008;27:1749-58.

106. Kahlert UD, Bender NO, Maciaczyk D, Bogiel T, Bar EE, Eberhart CG, et al. CD133/CD15 defines distinct cell subpopulations with differential in vitro 
clonogenic activity and stem cell-related gene expression profile in in vitro propagated glioblastoma multiforme-derived cell line with a PNET-like component. Folia Neuropathol. 2012;50:357-68.

107. Son MJ, Woolard K, Nam DH, Lee J, Fine HA. SSEA-1 is an enrichment marker for tumor-initiating cells in human glioblastoma. Cell Stem Cell. 2009;4:440-52.

108. Suva ML, Riggi N, Stehle JC, Baumer K, Tercier S, Joseph JM, et al. Identification of cancer stem cells in Ewing's sarcoma. Cancer Res. 2009;69:1776-81.

109. Tirino V, Desiderio V, Paino F, De Rosa A, Papaccio F, Fazioli F, et al. Human primary bone sarcomas contain CD133+ cancer stem cells displaying high tumorigenicity in vivo. Faseb J. 2011:25:2022-30.

110. Adhikari AS, Agarwal N, Wood BM, Porretta C, Ruiz B, Pochampally RR, et al. CD117 and Stro-1 identify osteosarcoma tumor-initiating cells associated with metastasis and drug resistance. Cancer Res. 2010;70:4602-12.

111. Tian J, Li X, Si M, Liu T, Li J. CD271+ osteosarcoma cells display stem-like properties. PLoS One. 2014;9:e98549.

112. Meirelles K, Benedict LA, Dombkowski D, Pepin D, Preffer FI, Teixeira J, et al. Human ovarian cancer stem/progenitor cells are stimulated by doxorubicin but inhibited by Mullerian inhibiting substance. Proc Natl Acad Sci U S A. 2012;109:2358-63.

113. Chen J, Wang J, Chen D, Yang J, Yang C, Zhang Y, et al. Evaluation of characteristics of CD44 + CD117+ ovarian cancer stem cells in three dimensional basement membrane extract scaffold versus two dimensional monocultures. BMC Cell Biol. 2013;14:7.

114. Curley MD, Therrien VA, Cummings $C L$, Sergent PA, Koulouris CR, Friel AM, et al. CD133 expression defines a tumor initiating cell population in primary human ovarian cancer. Stem Cells. 2009;27:2875-83.

115. Guo C, Liu H, Zhang BH, Cadaneanu RM, Mayle AM, Garraway IP. Epcam, CD44, and CD49f distinguish sphere-forming human prostate basal cells from a subpopulation with predominant tubule initiation capability. PLoS One. 2012;7:e34219.

116. Hurt EM, Kawasaki BT, Klarmann GJ, Thomas SB, Farrar WL. CD44+ CD24(-) prostate cells are early cancer progenitor/stem cells that provide a model for patients with poor prognosis. Br J Cancer. 2008;98:756-65.

117. Maitland NJ, Collins AT. Prostate cancer stem cells: a new target for therapy. J Clin Oncol. 2008;26:2862-70.

118. Boiko AD, Razorenova OV, van de Rijn M, Swetter SM, Johnson DL, Ly DP, et al. Human melanoma-initiating cells express neural crest nerve growth factor receptor CD271. Nature. 2010;466:133-7.

119. Wilson BJ, Saab KR, Ma J, Schatton T, Putz P, Zhan Q, et al. ABCB5 maintains melanoma-initiating cells through a proinflammatory cytokine signaling circuit. Cancer Res. 2014;74:4196-207.

120. Mirkina I, Hadzijusufovic E, Krepler C, Mikula M, Mechtcheriakova D, Strommer $\mathrm{S}$, et al. Phenotyping of human melanoma cells reveals a unique composition of receptor targets and a subpopulation co-expressing ErbB4, EPO-R and NGF-R. PLoS One. 2014;9:e84417.

121. Yui S, Nakamura T, Sato T, Nemoto $Y$, Mizutani T, Zheng $X$, et al. Functional engraftment of colon epithelium expanded in vitro from a single adult Lgr5 (+) stem cell. Nat Med. 2012;18:618-23.

122. Kemper K, Prasetyanti PR, De Lau W, Rodermond H, Clevers H, Medema JP. Monoclonal antibodies against Lgr5 identify human colorectal cancer stem cells. Stem Cells. 2012;30:2378-86.

123. Yu F, Yao $H$, Zhu $P$, Zhang $X$, Pan $Q$, Gong $C$, et al. let-7 regulates self renewal and tumorigenicity of breast cancer cells. Cell. 2007;131:1109-23.

124. Ginestier C, Hur MH, Charafe-Jauffret E, Monville F, Dutcher J, Brown M, et al. ALDH1 is a marker of normal and malignant human mammary stem cells and a predictor of poor clinical outcome. Cell Stem Cell. 2007;1:555-67.

125. Takagi S, Saito Y, Hijikata A, Tanaka S, Watanabe T, Hasegawa T, et al. Membrane-bound human SCF/KL promotes in vivo human hematopoietic engraftment and myeloid differentiation. Blood. 2012;119:2768-77.

126. Sarry JE, Murphy K, Perry R, Sanchez PV, Secreto A, Keefer C, et al. Human acute myelogenous leukemia stem cells are rare and heterogeneous when assayed in NOD/SCID/L2Rgammac-deficient mice. J Clin Invest. 2011;121:384-95

127. Vercauteren SM, Sutherland HJ. CD133 (AC133) expression on AML cells and progenitors. Cytotherapy. 2001;3:449-59.

128. Valent P, Bonnet D, Wohrer S, Andreeff M, Copland M, Chomienne C, et al. Heterogeneity of Neoplastic Stem Cells: Theoretical, Functional, and Clinical Implications. Cancer Res. 2013;73:1037-45.

129. Chaffer CL, Brueckmann I, Scheel C, Kaestli AJ, Wiggins PA, Rodrigues LO, et al. Normal and neoplastic nonstem cells can spontaneously convert to a stem-like state. Proc Natl Acad Sci U S A. 2011;108:7950-5.
130. Valent P, Bonnet D, De Maria R, Lapidot T, Copland M, Melo JV, et al. Cancer stem cell definitions and terminology: the devil is in the details. Nat Rev Cancer. 2012;12:767-75.

131. Jan M, Snyder TM, Corces-Zimmerman MR, Vyas P, Weissman IL, Quake SR, et al. Clonal evolution of preleukemic hematopoietic stem cells precedes human acute myeloid leukemia. Sci Transl Med. 2012;4:149ra118.

132. Valent $P$, Lion T, Wolf $D$, Sillaber $C$, Agis H, Petzer A, et al. Diagnostic algorithms, monitoring, prognostication, and therapy in chronic myeloid leukemia (CML): a proposal of the Austrian CML platform. Wien Klin Wochenschr. 2008;120:697-709.

133. Renström J, Kröger M, Peschel C, Oostendorp RAJ. How the niche regulates hematopoietic stem cells. Chem Biol Interact. 2010;184:7-15.

134. Wang P, Hou SX. Regulation of intestinal stem cells in mammals and Drosophila. J Cell Physiol. 2009:222:33-7.

135. Nguyen LV, Vanner R, Dirks P, Eaves CJ. Cancer stem cells: an evolving concept. Nat Rev Cancer. 2012;12:133-43.

136. Niebuhr B, Fischer M, Tager M, Cammenga J, Stocking C. Gatekeeper function of the RUNX1 transcription factor in acute leukemia. Blood Cells Mol Dis. 2008:40:211-8.

137. Wang X, Tripodi J, Kremyanskaya M, Blouin A, Roda P, Hoffman R, et al. BCR-ABL1 is a secondary event after JAK2V617F in patients with polycythemia vera who develop chronic myeloid leukemia. Blood. 2013;121:1238-9.

138. Itzykson R, Solary E. An evolutionary perspective on chronic myelomonocytic leukemia. Leukemia. 2013;27:1441-50.

139. Herrmann H. Phenotypic and functional characterization of CD34+/CD38 -/CD123+ leukemic progenitor (stem) cells in AML: a flow cytometric approach. In: 50th ASH Annual Meeting and Exposition. 2008.

140. Morimoto K, Kim SJ, Tanei T, Shimazu K, Tanji Y, Taguchi T, et al. Stem cell marker aldehyde dehydrogenase 1-positive breast cancers are characterized by negative estrogen receptor, positive human epidermal growth factor receptor type 2, and high Ki67 expression. Cancer Sci. 2009;100:1062-8.

141. Korkaya H, Paulson A, lovino F, Wicha MS. HER2 regulates the mammary stem/progenitor cell population driving tumorigenesis and invasion. Oncogene. 2008;27:6120-30.

142. Hewish M, Chau I, Cunningham D. Insulin-like growth factor 1 receptor targeted therapeutics: novel compounds and novel treatment strategies for cancer medicine. Recent Patents Anticancer Drug Discov. 2009;4:54-72.

143. Gotoh N. Control of stemness by fibroblast growth factor signaling in stem cells and cancer stem cells. Curr Stem Cell Res Ther. 2009:4:9-15.

144. Koneczny I, Schulenburg A, Hudec X, Knofler M, Holzmann K, Piazza G, et al. Autocrine fibroblast growth factor 18 signaling mediates Wnt-dependent stimulation of CD44-positive human colorectal adenoma cells. Mol Carcinog. 2014. doi:10.1002/mc.22146.

145. Jiang X, Lopez A, Holyoake T, Eaves A, Eaves C. Autocrine production and action of IL-3 and granulocyte colony-stimulating factor in chronic myeloid leukemia. Proc Natl Acad Sci U S A. 1999;96:12804-9.

146. Jiang X, Fujisaki T, Nicolini F, Berger M, Holyoake T, Eisterer W, et al. Autonomous multi-lineage differentiation in vitro of primitive CD34+ cells from patients with chronic myeloid leukemia. Leukemia. 2000;14:1112-21.

147. Zhang SS, Han ZP, Jing YY, Tao SF, Li TJ, Wang H, et al. CD133(+)CXCR4(+) colon cancer cells exhibit metastatic potential and predict poor prognosis of patients. BMC Med. 2012;10:85.

148. Furusato B, Mohamed A, Uhlen M, Rhim JS. CXCR4 and cancer. Pathol Int. 2010;60:497-505

149. Tavor S, Petit I. Can inhibition of the SDF-1/CXCR4 axis eradicate acute leukemia? Semin Cancer Biol. 2010;20:178-85.

150. Tavor S, Petit I, Porozov S, Avigdor A, Dar A, Leider-Trejo L, et al. CXCR4 regulates migration and development of human acute myelogenous leukemia stem cells in transplanted NOD/SCID mice. Cancer Res. 2004;64:2817-24.

151. Kumar SM, Zhang G, Bastian BC, Arcasoy MO, Karande P, Pushparajan A, et al. Erythropoietin receptor contributes to melanoma cell survival in vivo. Oncogene. 2012;31:1649-60.

152. Sinclair AM, Todd MD, Forsythe K, Knox SJ, Elliott S, Begley CG. Expression and function of erythropoietin receptors in tumors: implications for the use of erythropoiesis-stimulating agents in cancer patients. Cancer. 2007;110:477-88.

153. Jelkmann W, Bohlius J, Hallek M, Sytkowski AJ. The erythropoietin receptor in normal and cancer tissues. Crit Rev Oncol Hematol. 2008;67:39-61.

154. Gonen M, Sun Z, Figueroa ME, Patel JP, Abdel-Wahab O, Racevskis J, et al. CD25 expression status improves prognostic risk classification in AML independent of established biomarkers: ECOG phase 3 trial, E1900. Blood. 2012;120:2297-306. 
155. Testa U, Riccioni R, Diverio D, Rossini A, Lo Coco F, Peschle C. Interleukin-3 receptor in acute leukemia. Leukemia. 2004;18:219-26.

156. Lowenberg B, van Putten W, Theobald M, Gmur J, Verdonck L, Sonneveld P, et al. Effect of priming with granulocyte colony-stimulating factor on the outcome of chemotherapy for acute myeloid leukemia. N Engl J Med. 2003;349:743-52

157. Frohling S, Schlenk RF, Breitruck J, Benner A, Kreitmeier S, Tobis K, et al. Prognostic significance of activating FLT3 mutations in younger adults (16 to 60 years) with acute myeloid leukemia and normal cytogenetics: a study of the AML Study Group UIm. Blood. 2002;100:4372-80.

158. Hassan HT, Zander A. Stem cell factor as a survival and growth factor in human normal and malignant hematopoiesis. Acta Haematol. 1996:95:257-62.

159. Uy GL, Rettig MP, Motabi $H$, McFarland K, Trinkaus KM, Hladnik LM, et al. A phase $1 / 2$ study of chemosensitization with the CXCR4 antagonist plerixafor in relapsed or refractory acute myeloid leukemia. Blood. 2012;119:3917-24.

160. Hanumanthu VS, Pirruccello SJ. GCSF-R expression in myelodysplastic and myeloproliferative disorders and blast dysmaturation in CML. Am J Clin Pathol. 2013;140:155-64.

161. Zhang Y, Guo Q, Zhao H, Zhao D, Wu X, Zhao W, et al. Expression of CXCR4 is an independent prognostic factor for overall survival and progression-free survival in patients with myelodysplastic syndrome. Med Oncol. 2013;30:341.

162. Nakata Y, Kimura A, Katoh O, Kawaishi K, Hyodo H, Abe K, et al. c-kit point mutation of extracellular domain in patients with myeloproliferative disorders. Br J Haematol. 1995;91:661-3.

163. Bogani C, Ponziani V, Guglielmelli P, Desterke C, Rosti V, Bosi A, et al. Hypermethylation of CXCR4 promoter in CD34+ cells from patients with primary myelofibrosis. Stem Cells. 2008;26:1920-30.

164. Smith BD, Kasamon YL, Kowalski J, Gocke C, Murphy K, Miller CB, et al. K562/ GM-CSF immunotherapy reduces tumor burden in chronic myeloid leukemia patients with residual disease on imatinib mesylate. Clin Cancer Res. 2010;16:338-47.

165. Corbin AS, O'Hare T, Gu Z, Kraft IL, Eiring AM, Khorashad JS, et al. KIT signaling governs differential sensitivity of mature and primitive CML progenitors to tyrosine kinase inhibitors. Cancer Res. 2013;73:5775-86.

166. Beider K, Darash-Yahana M, Blaier O, Koren-Michowitz M, Abraham M, Wald $\mathrm{H}$, et al. Combination of imatinib with CXCR4 antagonist BKT140 overcomes the protective effect of stroma and targets CML in vitro and in vivo. Mol Cancer Ther. 2014;13:1155-69.

167. Gaikwad AS, Donohue RE, Elghetany MT, Sheehan AM, Lu XY, Gramatges $M M$, et al. Expression of CD25 is a specific and relatively sensitive marker for the Philadelphia chromosome (BCR-ABL1) translocation in pediatric $B$ acute lymphoblastic leukemia. Int J Clin Exp Pathol. 2014;7:6225-30.

168. Kim HP, Frankel AE, Hogge DE. A diphtheria toxin interleukin-3 fusion protein synergizes with tyrosine kinase inhibitors in killing leukemic progenitors from BCR/ABL positive acute leukemia. Leuk Res. 2010;34:1035-42.

169. Parameswaran R, Yu M, Lim M, Groffen J, Heisterkamp N. Combination of drug therapy in acute lymphoblastic leukemia with a CXCR4 antagonist. Leukemia. 2011;25:1314-23.

170. Peled A, Abraham M, Avivi I, Rowe JM, Beider K, Wald H, et al. The highaffinity CXCR4 antagonist BKT140 is safe and induces a robust mobilization of human CD34+ cells in patients with multiple myeloma. Clin Cancer Res. 2014;20:469-79.

171. LeBedis C, Chen K, Fallavollita L, Boutros T, Brodt P. Peripheral lymph node stromal cells can promote growth and tumorigenicity of breast carcinoma cells through the release of IGF-I and EGF. Int J Cancer. 2002;100:2-8.

172. Korkaya H, Wicha MS. HER2 and breast cancer stem cells: more than meets the eye. Cancer Res. 2013:73:3489-93.

173. Fillmore CM, Gupta PB, Rudnick JA, Caballero S, Keller PJ, Lander ES, et al. Estrogen expands breast cancer stem-like cells through paracrine FGF/Tbx3 signaling. Proc Natl Acad Sci U S A. 2010;107:21737-42.

174. Sun L, Wu G, Willson JK, Zborowska E, Yang J, Rajkarunanayake I, et al. Expression of transforming growth factor beta type $\|$ receptor leads to reduced malignancy in human breast cancer MCF-7 cells. J Biol Chem. 1994;269:26449-55

175. Pinto C, Di Fabio F, Siena S, Cascinu S, Rojas Llimpe FL, Ceccarelli C, et al. Phase II study of cetuximab in combination with FOLFIRI in patients with untreated advanced gastric or gastroesophageal junction adenocarcinoma (FOLCETUX study). Ann Oncol. 2007;18:510-7.

176. Bang YJ, Van Cutsem E, Feyereislova A, Chung HC, Shen L, Sawaki A, et al. Trastuzumab in combination with chemotherapy versus chemotherapy alone for treatment of HER2-positive advanced gastric or gastrooesophageal junction cancer (ToGA): a phase 3, open-label, randomised controlled trial. Lancet. 2010;376:687-97.

177. Shaib W, Mahajan R, El-Rayes B. Markers of resistance to anti-EGFR therapy in colorectal cancer. J Gastrointest Oncol. 2013;4:308-18.

178. Kim J, Takeuchi H, Lam ST, Turner RR, Wang HJ, Kuo C, et al. Chemokine receptor CXCR4 expression in colorectal cancer patients increases the risk for recurrence and for poor survival. J Clin Oncol. 2005;23:2744-53.

179. Wolpin BM, Meyerhardt JA, Chan AT, Ng K, Chan JA, Wu K, et al. Insulin, the insulin-like growth factor axis, and mortality in patients with nonmetastatic colorectal cancer. J Clin Oncol. 2009;27:176-85.

180. Calon A, Espinet E, Palomo-Ponce S, Tauriello DV, Iglesias M, Cespedes MV, et al. Dependency of colorectal cancer on a TGF-beta-driven program in stromal cells for metastasis initiation. Cancer Cell. 2012;22:571-84.

181. Okamoto I, Araki J, Suto R, Shimada M, Nakagawa K, Fukuoka M. EGFR mutation in gefitinib-responsive small-cell lung cancer. Ann Oncol. 2006;17:1028-9.

182. Moore MJ, Goldstein D, Hamm J, Figer A, Hecht JR, Gallinger S, et al. Erlotinib plus gemcitabine compared with gemcitabine alone in patients with advanced pancreatic cancer: a phase III trial of the National Cancer Institute of Canada Clinical Trials Group. J Clin Oncol. 2007:25:1960-6.

183. Shan J, Shen J, Liu L, Xia F, Xu C, Duan G, et al. Nanog regulates selfrenewal of cancer stem cells through the insulin-like growth factor pathway in human hepatocellular carcinoma. Hepatology. 2012;56:1004-14

184. Libermann TA, Nusbaum HR, Razon N, Kris R, Lax I, Soreq H, et al. Amplification, enhanced expression and possible rearrangement of EGF receptor gene in primary human brain tumours of glial origin. Nature. 1985:313:144-7.

185. Hermanson M, Funa K, Hartman M, Claesson-Welsh L, Heldin CH, Westermark $B$, et al. Platelet-derived growth factor and its receptors in human glioma tissue: expression of messenger RNA and protein suggests the presence of autocrine and paracrine loops. Cancer Res. 1992;52:3213-9.

186. Ehtesham M, Mapara KY, Stevenson CB, Thompson RC. CXCR4 mediates the proliferation of glioblastoma progenitor cells. Cancer Lett. 2009;274:305-12.

187. Penuelas S, Anido J, Prieto-Sanchez RM, Folch G, Barba I, Cuartas I, et al. TGF-beta increases glioma-initiating cell self-renewal through the induction of LIF in human glioblastoma. Cancer Cell. 2009;15:315-27.

188. Joo KM, Jin J, Kim E, Ho Kim K, Kim Y, Gu Kang B, et al. MET signaling regulates glioblastoma stem cells. Cancer Res. 2012;72:3828-38.

189. Glaysher S, Bolton LM, Johnson P, Atkey N, Dyson M, Torrance C, et al. Targeting EGFR and PI3K pathways in ovarian cancer. Br J Cancer. 2013;109:1786-94.

190. Bookman MA, Darcy KM, Clarke-Pearson D, Boothby RA, Horowitz IR. Evaluation of monoclonal humanized anti-HER2 antibody, trastuzumab, in patients with recurrent or refractory ovarian or primary peritoneal carcinoma with overexpression of HER2: a phase II trial of the Gynecologic Oncology Group. J Clin Oncol. 2003;21:283-90.

191. Yeung TL, Leung CS, Wong KK, Samimi G, Thompson MS, Liu J, et al. TGFbeta modulates ovarian cancer invasion by upregulating CAF-derived versican in the tumor microenvironment. Cancer Res. 2013;73:5016-28.

192. Dubrovska A, Elliott J, Salamone RJ, Telegeev GD, Stakhovsky AE, Schepotin IB, et al. CXCR4 expression in prostate cancer progenitor cells. PLoS One. 2012; $7:$ :e31226

193. Singh S, Nannuru KC, Sadanandam A, Varney ML, Singh RK. CXCR1 and CXCR2 enhances human melanoma tumourigenesis, growth and invasion. Br J Cancer. 2009:100:1638-46.

194. Karamboulas C, Ailles L. Developmental signaling pathways in cancer stem cells of solid tumors. Biochim Biophys Acta. 1830;2013:2481-95.

195. Okuhashi Y, Itoh M, Nara N, Tohda S. Effects of combination of Notch inhibitor plus hedgehog inhibitor or Wnt inhibitor on growth of leukemia cells. Anticancer Res. 2011;31:893-6.

196. Sinclair A, Latif AL, Holyoake TL. Targeting survival pathways in chronic myeloid leukaemia stem cells. Br J Pharmacol. 2013;169:1693-707.

197. Abetov D, Mustapova Z, Saliev T, Bulanin D. Biomarkers and signaling pathways of colorectal cancer stem cells. Tumour Biol. 2015;doi:10.1007/ s13277-015-3198-4

198. Takahashi-Yanaga F, Kahn M. Targeting Wnt signaling: can we safely eradicate cancer stem cells? Clin Cancer Res. 2010;16:3153-62.

199. Dey A, Seshasayee D, Noubade R, French DM, Liu J, Chaurushiya MS, et al. Loss of the tumor suppressor BAP1 causes myeloid transformation. Science. 2012;337:1541-6. 
200. Kleppe M, Levine RL. Targeting beta-catenin in CML: leukemia stem cells beware! Cell Stem Cell. 2012;10:351-3.

201. Pannuti A, Foreman K, Rizzo P, Osipo C, Golde T, Osborne B, et al. Targeting Notch to target cancer stem cells. Clin Cancer Res. 2010;16:3141-52.

202. Merchant AA, Matsui W. Targeting hedgehog - a cancer stem cell pathway. Clin Cancer Res. 2010;16:3130-40.

203. Druker BJ, Tamura S, Buchdunger E, Ohno S, Segal GM, Fanning S, et al. Effects of a selective inhibitor of the Abl tyrosine kinase on the growth of Bcr-Abl positive cells. Nat Med. 1996:2:561-6.

204. Corbin AS, Agarwal A, Loriaux M, Cortes J, Deininger MW, Druker BJ. Human chronic myeloid leukemia stem cells are insensitive to imatinib despite inhibition of BCR-ABL activity. J Clin Invest. 2011;121:396-409.

205. Hamilton A, Elrick L, Myssina S, Copland M, Jorgensen H, Melo JV, et al. BCR$\mathrm{ABL}$ activity and its response to drugs can be determined in CD34+ CML stem cells by CrkL phosphorylation status using flow cytometry. Leukemia. 2006;20:1035-9.

206. Wiseman DH, Greystoke BF, Somervaille TC. The variety of leukemic stem cells in myeloid malignancy. Oncogene. 2013;33(24):3091-8.

207. Anderson K, Lutz C, van Delft FW, Bateman CM, Guo Y, Colman SM, et al. Genetic variegation of clonal architecture and propagating cells in leukaemia. Nature. 2011:469:356-61.

208. Ysebaert L, Chicanne G, Demur C, De Toni F, Prade-Houdellier N, Ruidavets $\mathrm{JB}$, et al. Expression of beta-catenin by acute myeloid leukemia cells predicts enhanced clonogenic capacities and poor prognosis. Leukemia. 2006:20:1211-6.

209. Li Y, Welm B, Podsypanina K, Huang SX, Chamorro M, Zhang XM, et al Evidence that transgenes encoding components of the Wnt signaling pathway preferentially induce mammary cancers from progenitor cells. Proc Natl Acad Sci U S A. 2003;100:15853-8.

210. Chien AJ, Moore EC, Lonsdorf AS, Kulikauskas RM, Rothberg BG, Berger AJ, et al. Activated Wnt/beta-catenin signaling in melanoma is associated with decreased proliferation in patient tumors and a murine melanoma model. Proc Natl Acad Sci U S A. 2009;106:1193-8.

211. Yang W, Yan HX, Chen L, Liu Q, He YQ, Yu LX, et al. Wnt/beta-catenin signaling contributes to activation of normal and tumorigenic liver progenitor cells. Cancer Res. 2008;68:4287-95.

212. Gursel DB, Berry N, Boockvar JA. The contribution of Notch signaling to glioblastoma via activation of cancer stem cell self-renewal: the role of the endothelial network. Neurosurgery. 2012;70:N19-21.

213. Sikandar SS, Pate KT, Anderson S, Dizon D, Edwards RA, Waterman ML, et al. NOTCH signaling is required for formation and self-renewal of tumorinitiating cells and for repression of secretory cell differentiation in colon cancer. Cancer Res. 2010;70:1469-78.

214. Lee CW, Simin K, Liu Q, Plescia J, Guha M, Khan A, et al. A functional Notch-survivin gene signature in basal breast cancer. Breast Cancer Res. 2008;10:R97

215. Liu SL, Dontu G, Mantle ID, Patel S, Ahn NS, Jackson KW, et al. Hedgehog signaling and Bmi-1 regulate self-renewal of normal and malignant human mammary stem cells. Cancer Res. 2006;66:6063-71.

216. Huang FT, Zhuan-Sun YX, Zhuang YY, Wei SL, Tang J, Chen WB, et al. Inhibition of Hedgehog signaling depresses self-renewal of pancreatic cancer stem cells and reverses chemoresistance. J Gastroen Hepatol. 2012;27:43.

217. Kawaguchi-Ihara N, Okuhashi Y, Itoh M, Murohashi I, Nara N, Tohda S. Promotion of the self-renewal capacity of human leukemia cells by sonic hedgehog protein. Anticancer Res. 2011;31:781-4.

218. Ferruzzi P, Mennillo F, De Rosa A, Giordano C, Rossi M, Benedetti G, et al. In vitro and in vivo characterization of a novel hedgehog signaling antagonist in human glioblastoma cell lines. Int J Cancer. 2012;131:E33-44.

219. Mazumdar T, DeVecchio J, Shi T, Jones J, Agyeman A, Houghton JA Hedgehog signaling drives cellular survival in human colon carcinoma cells. Cancer Res. 2011;71:1092-102.

220. Phelps RA, Chidester S, Dehghanizadeh S, Phelps J, Sandoval IT, Rai K, et al. A two-step model for colon adenoma initiation and progression caused by APC loss. Cell. 2009;137:623-34.

221. Korkaya H, Paulson A, Charafe-Jauffret E, Ginestier C, Brown M, Dutcher J, et al. Regulation of mammary stem/progenitor cells by PTEN/Akt/betacatenin signaling. PLoS Biol. 2009;7:e1000121.

222. Kroon P, Berry PA, Stower MJ, Rodrigues G, Mann VM, Simms M, et al. JAKSTAT blockade inhibits tumor initiation and clonogenic recovery of prostate cancer stem-like cells. Cancer Res. 2013;73:5288-98.
223. Kanno H, Sato H, Yokoyama T-A, Yoshizumi T, Yamada S. The VHL tumor suppressor protein regulates tumorigenicity of U87-derived glioma stem-like cells by inhibiting the JAK/STAT signaling pathway. Int J Oncol. 2013:42:881-6.

224. Krause DS, Lazarides $K$, von Andrian UH, Van Etten RA. Requirement for CD44 in homing and engraftment of BCR-ABL-expressing leukemic stem cells. Nat Med. 2006;12:1175-80.

225. Nair RR, Tolentino J, Hazlehurst LA. The bone marrow microenvironment as a sanctuary for minimal residual disease in CML. Biochem Pharmacol. 2010;80:602-12

226. Potten CS, Loeffler M. Stem cells: attributes, cycles, spirals, pitfalls and uncertainties. Lessons for and from the crypt. Development. 1990;110:1001-20.

227. Jones DL, Wagers AJ. No place like home: anatomy and function of the stem cell niche. Nat Rev Mol Cell Biol. 2008:9:11-21.

228. Rosel M, Khaldoyanidi S, Zawadzki V, Zoller M. Involvement of CD44 variant isoform $v 10$ in progenitor cell adhesion and maturation. Exp Hematol. 1999;27:698-711

229. Alakel N, Jing D, Muller K, Bornhauser M, Ehninger G, Ordemann R. Direc contact with mesenchymal stromal cells affects migratory behavior and gene expression profile of CD133(+) hematopoietic stem cells during ex vivo expansion. Exp Hematol. 2009;37(4):504-13.

230. Raveh S, Gavert N, Ben-Ze'ev A. L1 cell adhesion molecule (L1CAM) in invasive tumors. Cancer Lett. 2009;282(2):137-45.

231. Gavert N, Ben-Shmuel A, Raveh S, Ben-Ze'ev A. L1-CAM in cancerous tissues. Expert Opin Biol Ther. 2008:8:1749-57.

232. Bao S, Wu Q, Li Z, Sathornsumetee S, Wang H, McLendon RE, et al. Targeting cancer stem cells through L1CAM suppresses glioma growth. Cancer Res. 2008;68:6043-8.

233. Kang Y, Massague J. Epithelial-mesenchymal transitions: twist in development and metastasis. Cell. 2004;118:277-9.

234. Peled A, Hardan I, Trakhtenbrot L, Gur E, Magid M, Darash-Yahana M, et al. Immature leukemic CD34(+)CXCR4(+) cells from CML patients have lower integrin-dependent migration and adhesion in response to the chemokine SDF-1. Stem Cells. 2002;20:259-66.

235. Zhang B, Ho YW, Huang Q, Maeda T, Lin A, Lee SU, et al. Altered microenvironmental regulation of leukemic and normal stem cells in chronic myelogenous leukemia. Cancer Cell. 2012;21:577-92.

236. Scadden DT. The stem-cell niche as an entity of action. Nature. 2006:441:1075-9.

237. Greenberger JS. The hematopoietic microenvironment. Crit Rev Oncol Hematol. 1991;11:65-84.

238. Torok-Storb B. Cellular interactions. Blood. 1988;72:373-85.

239. Mayani H, Guilbert LJ, Janowska-Wieczorek A. Biology of the hemopoietic microenvironment. Eur J Haematol. 1992:49:225-33.

240. Springer TA. Traffic signals for lymphocyte recirculation and leukocyte emigration: the multistep paradigm. Cell. 1994;76:301-14.

241. Fidler IJ. The pathogenesis of cancer metastasis: the 'seed and soil' hypothesis revisited. Nat Rev Cancer. 2003;3:453-8.

242. Diacovo TG, Roth SJ, Buccola JM, Bainton DF, Springer TA. Neutrophil rolling, arrest, and transmigration across activated, surface-adherent platelets via sequential action of P-selectin and the beta 2-integrin CD11b/CD18. Blood. 1996:88:146-57.

243. Schulenburg A, Cech P, Herbacek I, Marian B, Wrba F, Valent P, et al. CD44positive colorectal adenoma cells express the potential stem cell markers musashi antigen (msi1) and ephrin B2 receptor (EphB2). J Pathol. 2007;213:152-60.

244. De Craene B, Berx G. Regulatory networks defining EMT during cancer initiation and progression. Nat Rev Cancer. 2013;13:97-110.

245. Savagner $P$. The epithelial-mesenchymal transition (EMT) phenomenon. Ann Oncol. 2010;21 Suppl 7:vii89-92

246. Durig J, Rosenthal C, Elmaagacli A, Heyworth C, Halfmeyer K, Kasper C, et al. Biological effects of stroma-derived factor-1 alpha on normal and CML CD34+ haemopoietic cells. Leukemia. 2000;14:1652-60.

247. Kunisaki Y, Bruns I, Scheiermann C, Ahmed J, Pinho S, Zhang D, et al. Arteriolar niches maintain haematopoietic stem cell quiescence. Nature. 2013;502:637-43

248. Scadden DT. Nice neighborhood: emerging concepts of the stem cell niche. Cell. 2014;157:41-50.

249. Morrison SJ, Scadden DT. The bone marrow niche for haematopoietic stem cells. Nature. 2014;505:327-34 
250. Konopleva M, Tabe $Y$, Zeng Z, Andreeff M. Therapeutic targeting of microenvironmental interactions in leukemia: mechanisms and approaches. Drug Resist Updat. 2009;12:103-13.

251. Sullivan WJ, Christofk HR. The metabolic milieu of metastases. Cell. 2015;160:363-4.

252. Xiang L, Gilkes DM, Hu H, Takano N, Luo W, Lu H, et al. Hypoxia-inducible factor 1 mediates TAZ expression and nuclear localization to induce the breast cancer stem cell phenotype. Oncotarget. 2014;5:12509-27.

253. Clarke L, van der Kooy D. Low oxygen enhances primitive and definitive neural stem cell colony formation by inhibiting distinct cell death pathways. Stem Cells. 2009;27:1879-86.

254. Moreno-Manzano V, Rodriguez-Jimenez FJ, Acena-Bonilla JL, Fustero-Lardies S, Erceg S, Dopazo J, et al. FM19G11, a new hypoxia-inducible factor (HIF) modulator, affects stem cell differentiation status. J Biol Chem. 2010;285:1333-42.

255. Levesque JP, Winkler IG, Hendy J, Williams B, Helwani F, Barbier V, et al. Hematopoietic progenitor cell mobilization results in hypoxia with increased hypoxia-inducible transcription factor-1 alpha and vascular endothelial growth factor A in bone marrow. Stem Cells. 2007;25:1954-65.

256. Ceradini DJ, Kulkarni AR, Callaghan MJ, Tepper OM, Bastidas N, Kleinman $\mathrm{ME}$, et al. Progenitor cell trafficking is regulated by hypoxic gradients through HIF-1 induction of SDF-1. Nat Med. 2004;10:858-64

257. Gustafsson MV, Zheng X, Pereira T, Gradin K, Jin S, Lundkvist J, et al. Hypoxia requires notch signaling to maintain the undifferentiated cell state. Dev Cell. 2005:9:617-28.

258. Chen Y, De Marco MA, Graziani I, Gazdar AF, Strack PR, Miele L, et al. Oxygen concentration determines the biological effects of $\mathrm{NOTCH}-1$ signaling in adenocarcinoma of the lung. Cancer Res. 2007;67:7954-9.

259. Gilbertson RJ, Rich JN. Making a tumour's bed: glioblastoma stem cells and the vascular niche. Nat Rev Cancer. 2007;7:733-6.

260. Nieborowska-Skorska M, Kopinski PK, Ray R, Hoser G, Ngaba D, Flis S, et al. Rac2-MRC-clll-generated ROS cause genomic instability in chronic myeloid leukemia stem cells and primitive progenitors. Blood. 2012;119:4253-63.

261. Kantner HP, Warsch W, Delogu A, Bauer E, Esterbauer H, Casanova E, et al. ETV6/RUNX1 induces reactive oxygen species and drives the accumulation of DNA damage in B cells. Neoplasia. 2013;15:1292-300.

262. Warsch W, Grundschober E, Berger A, Gille L, Cerny-Reiterer S, Tigan AS, et al. STAT5 triggers BCR-ABL1 mutation by mediating ROS production in chronic myeloid leukaemia. Oncotarget. 2012;3:1669-87.

263. Covello KL, Kehler J, Yu H, Gordan JD, Arsham AM, Hu CJ, et al. HIF-2alpha regulates Oct-4: effects of hypoxia on stem cell function, embryonic development, and tumor growth. Genes Dev. 2006;20:557-70.

264. Keith B, Simon MC. Hypoxia-inducible factors, stem cells, and cancer. Cell. 2007;129:465-72.

265. Horton SJ, Huntly BJ. Recent advances in acute myeloid leukemia stem cell biology. Haematologica. 2012;97:966-74

266. Oh SH, Park TS, Kim HR, Lee JY, Kim JH, Shin JH, et al. Chronic myelogenous leukemia showing biphenotypic blast crisis followed by lineage switch to $B$ lymphoblastic leukemia. Leuk Res. 2009;33:e195-8.

267. Schmidt CA, Przybylski GK. What can we learn from leukemia as for the process of lineage commitment in hematopoiesis? Int Rev Immunol. 2001;20:107-15.

268. Reid AG, De Melo VA, Elderfield K, Clark I, Marin D, Apperley J, et al. Phenotype of blasts in chronic myeloid leukemia in blastic phase-analysis of bone marrow trephine biopsies and correlation with cytogenetics. Leuk Res. 2009;33:418-25.

269. Bettelheim P, Lutz D, Majdic O, Paietta E, Haas O, Linkesch W, et al. Cell lineage heterogeneity in blast crisis of chronic myeloid leukaemia. $\mathrm{Br}$ J Haematol. 1985;59:395-409.

270. Goradia A, Bayerl M, Cornfield D. The 8p11 myeloproliferative syndrome: review of literature and an illustrative case report. Int J Clin Exp Pathol. 2008;1:448-56.

271. Tzankov A, Sotlar K, Muhlematter D, Theocharides A, Went $P$, Jotterand M et al. Systemic mastocytosis with associated myeloproliferative disease and precursor B lymphoblastic leukaemia with t(13;13)(q12;q22) involving FLT3. J Clin Pathol. 2008;61:958-61.

272. Sperr WR, Horny HP, Valent P. Spectrum of associated clonal hematologic non-mast cell lineage disorders occurring in patients with systemic mastocytosis. Int Arch Allergy Immunol. 2002;127:140-2

273. Streubel B, Chott A, Huber D, Exner M, Jager U, Wagner O, et al. Lymphoma-specific genetic aberrations in microvascular endothelial cells in B-cell lymphomas. N Engl J Med. 2004;351:250-9.
274. Gunsilius E, Duba HC, Petzer AL, Kahler CM, Grunewald K, Stockhammer G, et al. Evidence from a leukaemia model for maintenance of vascular endothelium by bone-marrow-derived endothelial cells. Lancet. 2000;355:1688-91.

275. Wu J, Huang L, Huang M, Liu W, Zheng M, Cao Y, et al. Dominant contribution of malignant endothelial cells to endotheliopoiesis in chronic myeloid leukemia. Exp Hematol. 2009;37:87-91.

276. Mirshahi P, Rafii A, Vincent L, Berthaut A, Varin R, Kalantar G, et al. Vasculogenic mimicry of acute leukemic bone marrow stromal cells. Leukemia. 2009:23:1039-48.

277. Hauswirth AW, Florian S, Printz D, Sotlar K, Krauth MT, Fritsch G, et al. Expression of the target receptor CD33 in CD34+/CD38-/CD123+ AML stem cells. Eur J Clin Invest. 2007;37:73-82.

278. Pearce DJ, Taussig DC, Bonnet D. Implications of the expression of myeloid markers on normal and leukemic stem cells. Cell Cycle. 2006;5:271-3.

279. Larson RA, Boogaerts M, Estey E, Karanes C, Stadtmauer EA, Sievers EL, et al. Antibody-targeted chemotherapy of older patients with acute myeloid leukemia in first relapse using Mylotarg (gemtuzumab ozogamicin). Leukemia. 2002;16:1627-36.

280. Sievers EL, Larson RA, Stadtmauer EA, Estey E, Lowenberg B, Dombret H, et al. Efficacy and safety of gemtuzumab ozogamicin in patients with CD33positive acute myeloid leukemia in first relapse. J Clin Oncol. 2001:19:3244-54

281. Feldman E, Kalaycio M, Weiner G, Frankel S, Schulman P, Schwartzberg L, et al. Treatment of relapsed or refractory acute myeloid leukemia with humanized anti-CD33 monoclonal antibody HuM195. Leukemia. 2003:17:314-8

282. Sievers EL, Appelbaum FR, Spielberger RT, Forman SJ, Flowers D, Smith FO, et al. Selective ablation of acute myeloid leukemia using antibody-targeted chemotherapy: a phase I study of an anti-CD33 calicheamicin immunoconjugate. Blood. 1999;93:3678-84.

283. Majeti R. Monoclonal antibody therapy directed against human acute myeloid leukemia stem cells. Oncogene. 2011;30:1009-19.

284. Mahon F-X, Rea D, Guilhot J, Guilhot F, Huquet F, Nicolini F, et al. Discontinuation of imatinib in patients with chronic myeloid leukaemia who have maintained complete molecular remission for at least 2 years: the prospective, multicentre Stop Imatinib (STIM) trial. Lancet Oncol. 2010;11:1029-35.

285. Pfreundschuh M, Schubert J, Ziepert M, Schmits R, Mohren M, Lengfelder E, et al. Six versus eight cycles of bi-weekly CHOP-14 with or without rituximab in elderly patients with aggressive CD20+ B-cell lymphomas: a randomised controlled trial (RICOVER-60). Lancet Oncol. 2008:9:105-16.

286. Patz M, Isaeva P, Forcob N, Muller B, Frenzel LP, Wendtner CM, et al. Comparison of the in vitro effects of the anti-CD20 antibodies rituximab and GA101 on chronic lymphocytic leukaemia cells. Br J Haematol. 2011;152:295-306.

287. Boyd K, Dearden CE. Alemtuzumab in the treatment of chronic lymphocytic lymphoma. Expert Rev Anticancer Ther. 2008:8:525-33.

288. Cunningham MP, Thomas H, Marks C, Green M, Fan Z, Modjtahedi H. Co-targeting the EGFR and IGF-IR with anti-EGFR monoclonal antibody ICR62 and the IGF-IR tyrosine kinase inhibitor NVP-AEW541 in colorectal cancer cells. Int J Oncol. 2008:33:1107-13.

289. Heinrich MC. Imatinib treatment of metastatic GIST: don't stop (believing). Lancet Oncol. 2010;11:910-1.

290. Burris 3rd HA, Hurwitz HI, Dees EC, Dowlati A, Blackwell KL, O’Neil B, et al. Phase I safety, pharmacokinetics, and clinical activity study of lapatinib (GW572016), a reversible dual inhibitor of epidermal growth factor receptor tyrosine kinases, in heavily pretreated patients with metastatic carcinomas. J Clin Oncol. 2005:23:5305-13.

291. Sekulic A, Migden MR, Oro AE, Dirix L, Lewis KD, Hainsworth JD, et al. Efficacy and safety of vismodegib in advanced basal-cell carcinoma. N Engl J Med. 2012;366:2171-9.

292. Ribas A, Flaherty KT. BRAF targeted therapy changes the treatment paradigm in melanoma. Nat Rev Clin Oncol. 2011;8:426-33.

293. Byrd JC, Furman RR, Coutre SE, Flinn IW, Burger JA, Blum KA, et al. Targeting BTK with ibrutinib in relapsed chronic lymphocytic leukemia. N Engl J Med. 2013;369:32-42

294. Galanis E, Buckner JC, Maurer MJ, Kreisberg Jl, Ballman K, Boni J, et al. Phase II trial of temsirolimus (CCl-779) in recurrent glioblastoma multiforme: a North Central Cancer Treatment Group Study. J Clin Oncol. 2005;23:5294-304.

295. Hudes GR. mTOR as a target for therapy of renal cancer. Clin Adv Hematol Oncol. 2007:5:772-4. 
296. Zuber J, Shi J, Wang E, Rappaport AR, Herrmann H, Sison EA, et al. RNAi screen identifies Brd4 as a therapeutic target in acute myeloid leukaemia. Nature. 2011;478:524-8.

297. Fons P, Herault JP, Delesque N, Tuyaret J, Bono F, Herbert JM. VEGF-R2 and neuropilin-1 are involved in VEGF-A-induced differentiation of human bone marrow progenitor cells. J Cell Physiol. 2004;200:351-9.

298. Shervington A, Lu C. Expression of multidrug resistance genes in normal and cancer stem cells. Cancer Invest. 2008;26:535-42.

299. Gottesman MM. Mechanisms of cancer drug resistance. Annu Rev Med. 2002;53:615-27.

300. Engler JR, Frede A, Saunders V, Zannettino A, White DL, Hughes TP. The poor response to imatinib observed in CML patients with low OCT-1 activity is not attributable to lower uptake of imatinib into their CD34+ cells. Blood. 2010;116:2776-8.

301. Patrawala L, Calhoun T, Schneider-Broussard R, Zhou J, Claypool K, Tang DG. Side population is enriched in tumorigenic, stem-like cancer cells, whereas ABCG2+ and ABCG2- cancer cells are similarly tumorigenic. Cancer Res. 2005;65:6207-19.

302. Nakai E, Park K, Yawata T, Chihara T, Kumazawa A, Nakabayashi H, et al. Enhanced MDR1 expression and chemoresistance of cancer stem cells derived from glioblastoma. Cancer Invest. 2009;27:901-8.

303. Yamamoto A, Shofuda T, Islam MO, Nakamura Y, Yamasaki M, Okano H, et al. ABCB1 is predominantly expressed in human fetal neural stem/ progenitor cells at an early development stage. J Neurosci Res. 2009:87:2615-23.

304. Jin W, Liu Y, Xu SG, Yin WJ, Li JJ, Yang JM, et al. UHRF1 inhibits MDR1 gene transcription and sensitizes breast cancer cells to anticancer drugs. Breast Cancer Res Treat. 2010;124:39-48.

305. Brendel C, Scharenberg C, Dohse M, Robey RW, Bates SE, Shukla S, et al. Imatinib mesylate and nilotinib (AMN107) exhibit high-affinity interaction with ABCG2 on primitive hematopoietic stem cells. Leukemia. 2007;21:1267-75.

306. Guzman ML, Neering SJ, Upchurch D, Grimes B, Howard DS, Rizzieri DA, et al. Nuclear factor-kappaB is constitutively activated in primitive human acute myelogenous leukemia cells. Blood. 2001;98:2301-7.

307. Zhang J, Grindley JC, Yin T, Jayasinghe S, He XC, Ross JT, et al. PTEN maintains haematopoietic stem cells and acts in lineage choice and leukaemia prevention. Nature. 2006:441:518-22.

308. Yilmaz OH, Valdez R, Theisen BK, Guo W, Ferguson DO, Wu H, et al. Pten dependence distinguishes haematopoietic stem cells from leukaemiainitiating cells. Nature. 2006;441:475-82.

309. Hess CJ, Berkhof J, Denkers F, Ossenkoppele GJ, Schouten JP, Oudejans JJ, et al. Activated intrinsic apoptosis pathway is a key related prognostic parameter in acute myeloid leukemia. J Clin Oncol. 2007;25:1209-15.

310. Harper LJ, Costea DE, Gammon L, Fazil B, Biddle A, Mackenzie IC. Normal and malignant epithelial cells with stem-like properties have an extended $\mathrm{G} 2$ cell cycle phase that is associated with apoptotic resistance. BMC Cancer 2010;10:166.

311. Hegi ME, Diserens AC, Gorlia T, Hamou MF, de Tribolet N, Weller M, et al. MGMT gene silencing and benefit from temozolomide in glioblastoma. N Engl J Med. 2005;352:997-1003

312. Skladanowski A, Bozko P, Sabisz M. DNA structure and integrity checkpoints during the cell cycle and their role in drug targeting and sensitivity of tumor cells to anticancer treatment. Chem Rev. 2009:109:2951-73.

313. Lane SW, Scadden DT, Gilliland DG. The leukemic stem cell niche: current concepts and therapeutic opportunities. Blood. 2009;114:1150-7.

314. Teitz-Tennenbaum S, Wicha MS, Chang AE, Li Q. Targeting cancer stem cells via dendritic-cell vaccination. Oncoimmunology. 2012;1:1401-3.

315. Brune M, Castaigne S, Catalano J, Gehlsen K, Ho AD, Hofmann WK, et al. Improved leukemia-free survival after postconsolidation immunotherapy with histamine dihydrochloride and interleukin-2 in acute myeloid leukemia: results of a randomized phase 3 trial. Blood. 2006;108:88-96.

316. Essers MA, Trumpp A. Targeting leukemic stem cells by breaking their dormancy. Mol Oncol. 2010;4:443-50.

317. Hodi FS, O'Day SJ, McDermott DF, Weber RW, Sosman JA, Haanen JB, et al. Improved survival with ipilimumab in patients with metastatic melanoma. N Engl J Med. 2010;363:711-23.

318. Topalian SL, Drake CG, Pardoll DM. Targeting the PD-1/B7-H1(PD-L1) pathway to activate anti-tumor immunity. Curr Opin Immunol. 2012;24:207-12.

319. Weber DM, Chen C, Niesvizky R, Wang M, Belch A, Stadtmauer EA, et al. Lenalidomide plus dexamethasone for relapsed multiple myeloma in North America. N Engl J Med. 2007;357:2133-42.
320. Bao S, Wu Q, Sathornsumetee S, Hao Y, Li Z, Hjelmeland AB, et al. Stem celllike glioma cells promote tumor angiogenesis through vascular endothelial growth factor. Cancer Res. 2006;66:7843-8

321. Wulf GG, Wang RY, Kuehnle I, Weidner D, Marini F, Brenner MK, et al. A leukemic stem cell with intrinsic drug efflux capacity in acute myeloid leukemia. Blood. 2001:98:1166-73.

322. Hirschmann-Jax C, Foster AE, Wulf GG, Nuchtern JG, Jax TW, Gobel U, et al. A distinct "side population" of cells with high drug efflux capacity in human tumor cells. Proc Natl Acad Sci U S A. 2004;101:14228-33.

323. Peter B, Cerny-Reiterer S, Hadzijusufovic E, Schuch K, Stefanzl G, Eisenwort G, et al. The pan-Bcl-2 blocker obatoclax promotes the expression of Puma Noxa, and Bim mRNA and induces apoptosis in neoplastic mast cells. J Leukoc Biol. 2014;95:95-104.

324. Moser C, Lang SA, Kainz S, Gaumann A, Fichtner-Feigl S, Koehl GE, et al. Blocking heat shock protein-90 inhibits the invasive properties and hepatic growth of human colon cancer cells and improves the efficacy of oxaliplatin in p53deficient colon cancer tumors in vivo. Mol Cancer Ther. 2007:6:2868-78.

325. Clappier E, Gerby B, Sigaux F, Delord M, Touzri F, Hernandez L, et al. Clonal selection in xenografted human T cell acute lymphoblastic leukemia recapitulates gain of malignancy at relapse. J Exp Med. 2011;208:653-61.

326. Hochhaus A. Chronic myelogenous leukemia $(\mathrm{CML})$ : resistance to tyrosine kinase inhibitors. Ann Oncol. 2006;17 Suppl 10:x274-9.

327. Druker BJ. Translation of the Philadelphia chromosome into therapy for CML. Blood. 2008;112:4808-17.

328. Gorre ME, Mohammed M, Ellwood K, Hsu N, Paquette R, Rao PN, et al, Clinical resistance to STI-571 cancer therapy caused by BCR-ABL gene mutation or amplification. Science. 2001;293:876-80.

329. Carter TA, Wodicka LM, Shah NP, Velasco AM, Fabian MA, Treiber DK, et al. Inhibition of drug-resistant mutants of $\mathrm{ABL}, \mathrm{KIT}$, and EGF receptor kinases. Proc Natl Acad Sci U S A. 2005;102:11011-6.

330. Deininger M. Resistance and relapse with imatinib in CML: causes and consequences. J Natl Compr Canc Netw. 2008;6 Suppl 2:S11-21.

331. Quintas-Cardama A, Kantarjian HM, Cortes JE. Mechanisms of primary and secondary resistance to imatinib in chronic myeloid leukemia. Cancer Control. 2009;16:122-31.

332. Andreeff M, Konopleva M. Mechanisms of drug resistance in AML. Cancer Treat Res. 2002;112:237-62.

333. Thomas X, Campos L, Le QH, Guyotat D. Heat shock proteins and acute leukemias. Hematology. 2005;10:225-35.

334. Haase D, Germing U, Schanz J, Pfeilstocker M, Nosslinger T, Hildebrandt B, et al. New insights into the prognostic impact of the karyotype in MDS and correlation with subtypes: evidence from a core dataset of 2124 patients. Blood. 2007:110:4385-95.

335. Mrozek K. Cytogenetic, molecular genetic, and clinical characteristics of acute myeloid leukemia with a complex karyotype. Semin Oncol. 2008;35:365-77.

336. Cortes JE, Talpaz M, Giles F, O'Brien S, Rios MB, Shan J, et al. Prognostic significance of cytogenetic clonal evolution in patients with chronic myelogenous leukemia on imatinib mesylate therapy. Blood. 2003;101:3794-800

337. Baccarani M, Deininger MW, Rosti G, Hochhaus A, Soverini S, Apperley JF, et al. European LeukemiaNet recommendations for the management of chronic myeloid leukemia: 2013. Blood. 2013;122:872-84.

338. Cortes JE, Kantarjian H, Shah NP, Bixby D, Mauro MJ, Flinn I, et al. Ponatinib in refractory Philadelphia chromosome-positive leukemias. N Engl J Med. 2012;367:2075-88

339. Blay JY. A decade of tyrosine kinase inhibitor therapy: historical and current perspectives on targeted therapy for GIST. Cancer Treat Rev. 2011;37:373-84.

340. Kanda T, Ishikawa T, Takahashi T, Nishida T. Nilotinib for treatment of gastrointestinal stromal tumors: out of the equation? Expert Opin Pharmacother. 2013;14:1859-67.

341. Iorio N, Sawaya RA, Friedenberg FK. Review article: the biology, diagnosis and management of gastrointestinal stromal tumours. Aliment Pharmacol Ther. 2014;39(12):1376-86.

342. Shoji S, Nakano M, Sato H, Tang XY, Osamura YR, Terachi T, et al. The current status of tailor-made medicine with molecular biomarkers for patients with clear cell renal cell carcinoma. Clin Exp Metastasis. 2014:31:111-34

343. Motzer RJ, Hutson TE, Cella D, Reeves J, Hawkins R, Guo J, et al. Pazopanib versus sunitinib in metastatic renal-cell carcinoma. $\mathrm{N}$ Engl J Med. 2013;369:722-31. 
344. Plosker GL, Figgitt DP. Rituximab: a review of its use in non-Hodgkin's lymphoma and chronic lymphocytic leukaemia. Drugs. 2003;63:803-43.

345. Cheson BD, Leonard JP. Monoclonal antibody therapy for B-cell nonHodgkin's lymphoma. N Engl J Med. 2008;359:613-26.

346. Agarwal A, Fleischman AG, Petersen CL, MacKenzie R, Luty S, Loriaux M, et al. Effects of plerixafor in combination with BCR-ABL kinase inhibition in a murine model of CML. Blood. 2012;120:2658-68.

347. Saglio G, Kim DW, Issaragrisil S, le Coutre P, Etienne G, Lobo C, et al. Nilotinib versus imatinib for newly diagnosed chronic myeloid leukemia. $\mathrm{N}$ Engl J Med. 2010;362:2251-9.

348. Khoury HJ, Cortes JE, Kantarjian HM, Gambacorti-Passerini C, Baccarani M, Kim DW, et al. Bosutinib is active in chronic phase chronic myeloid leukemia after imatinib and dasatinib and/or nilotinib therapy failure. Blood. 2012;119:3403-12.

349. Damon LE. Mobilization of hematopoietic stem cells into the peripheral blood. Expert Rev Hematol. 2009;2:717-33.

350. Uy GL, Rettig MP, Cashen AF. Plerixafor, a CXCR4 antagonist for the mobilization of hematopoietic stem cells. Expert Opin Biol Ther. 2008:8:1797-804.

351. Hadzijusufovic E, Herndlhofer S, Aichberger K, Ghanim V, Suppan V, CernyReiterer S, et al. Nilotinib exerts direct effects on vascular endothelial cells and may act as a co-trigger of atherosclerosis in patients with Ph plus CML. Blood. 2011;118:1183-4.

352. Perl A, Carroll M. BCR-ABL kinase is dead; long live the CML stem cell. J Clin Invest. 2011;121:22-5.

353. Hamilton A, Helgason GV, Schemionek M, Zhang B, Myssina S, Allan EK, et al. Chronic myeloid leukemia stem cells are not dependent on Bcr-Abl kinase activity for their survival. Blood. 2012;119:1501-10.

\section{Submit your next manuscript to BioMed Central and take full advantage of:}

- Convenient online submission

- Thorough peer review

- No space constraints or color figure charges

- Immediate publication on acceptance

- Inclusion in PubMed, CAS, Scopus and Google Scholar

- Research which is freely available for redistribution 